\title{
BOREAS
}

\section{Paleoceanographic changes in the North Atlantic during the Mid-Pleistocene Transition (MIS 31-19) as inferred from planktonic foraminifera and calcium carbonate records}

\begin{tabular}{|r|l|}
\hline Journal: & Boreas \\
\hline Manuscript ID: & BOR-066-2011.R2 \\
\hline Manuscript Type: & Original Article \\
\hline Date Submitted by the Author: & n/a \\
\hline Complete List of Authors: & $\begin{array}{l}\text { Hernández Almeida, Iván; University of Bern, Institute of Geography and } \\
\text { Oeschger Centre for Climate Change Research; University of Salamanca, } \\
\text { Geology } \\
\text { Sierro, Francisco; University of Salamanca, Geology } \\
\text { Cacho, Isabel; University of Barcelona, Stratigraphy, Paleontology and } \\
\text { Marine Geosciences } \\
\text { Filippelli, Gabriel; IUPUI, Earth Sciences; } \\
\text { Flores, José; University of Salamanca, Geology }\end{array}$ \\
\hline Keywords: & $\begin{array}{l}\text { North Atlantic, Mid-Pleistocene Transition, planktonic foraminifera, } \\
\text { Neogloboquadrina pachyderma sinistral, CaCO3, intermediate ventilation, } \\
\text { Arctic Front }\end{array}$ \\
\hline & \multicolumn{2}{|l}{} \\
\hline
\end{tabular}




\title{
Paleoceanographic changes in the North Atlantic during the Mid-Pleistocene Transition
} (MIS 31-19) as inferred from planktonic foraminifera and calcium carbonate records

\author{
Iván Hernández-Almeida (ivan.hernandez@giub.unibe.ch $)^{\dagger}, \quad$ Francisco Javier Sierro
} (sierro@usal.es) and José-Abel Flores (flores@usal.es), Department of Geology, University of Salamanca, Faculty of Sciences, 37008 Salamanca, Spain; Isabel Cacho (icacho@ub.edu), GRC Marine Geosciences, Department of Stratigraphy, Paleontology and Marine Geosciences, University of Barcelona, 08028 Barcelona, Spain; Gabriel Michael Filippelli (gfilippe@iupui.edu), Department of Earth Sciences, Indiana University-Purdue University Indianapolis (IUPUI), 46202 Indianapolis, USA.

${ }^{\dagger}$ Now at: Institute of Geography and Oeschger Centre for Climate Change Research, University of Bern, 3012 Bern, Switzerland.

Marine sediments from the Integrated Ocean Drilling Project (IODP) Site U1314 $\left(56.36^{\circ} \mathrm{N}\right.$, $27.88^{\circ} \mathrm{W}$ ), in the subpolar North Atlantic were studied for their planktonic foraminifera, calcium carbonate content, and Neogloboqudrina pachyderma sinistral (sin.) $\delta^{13} \mathrm{C}$ records in order to reconstruct surface and intermediate conditions in this region during the MidPleistocene Transition (MPT). Variations in paleoceanography and regional dynamic of the Arctic Front were estimated comparing $\mathrm{CaCO}_{3}$ content, planktonic foraminifera species abundances, carbon isotopes and ice rafted detritus (IRD) data from Site U1314 with published data from other North Atlantic sites. Site U1314 exhibited high abundances of polar planktonic foraminifera $N$. pachyderma sin. and low $\mathrm{CaCO}_{3}$ content until Marine Isotope Stage (MIS) 26, indicating a relatively south-eastward position of the Arctic Front (AF) and penetration of colder and low saline surface arctic water masses. Changing conditions after MIS 25, with oscillations in the position of the AF, caused an increase in the northward export 
of warmer North Atlantic Current (NAC), indicated by more abundance of non-polar planktonic foraminifera and higher $\mathrm{CaCO}_{3}$. The N. pachyderma $\sin . \delta^{13} \mathrm{C}$ data indicate good ventilation of the upper-part of the intermediate water layer in the eastern North Atlantic during both glacial and interglacial stages, except during Terminations 24/23, 22/21 and 20/1. In addition, for N. pachyderma (sin.) we distinguished two morphotypes; nonencrusted and heavily encrusted test. Results indicate that increases in the encrusted morphotype and lower plaktonic foraminifera diversity are related to intensification of glacial conditions (lower seasurface temperatures, sea-ice formation) during MIS 22 and 20.

Key words: North Atlantic; Mid-Pleistocene Transition; planktonic foraminifera; Neogloboquadrina pachyderma sinistral; intermediate ventilation; $\mathrm{CaCO}_{3}$; Arctic Front.

Detailed analyses of high-latitude North Atlantic sediment cores and the development of paleoclimatic models have demonstrated the persistence of cyclical ice-volume variations and abrupt global climate changes throughout the Pleistocene Epoch. Especially intriguing is the period between 1100 and 700 ka, known as the "Mid-Pleistocene Transition" (MPT) (Berger \& Jansen 1994), when there was a large build-up of ice sheets in the Northern Hemisphere, producing higher amplitude climate oscillations (Mudelsee \& Schulz 1997; Tziperman \& Gildor 2003; Clark et al. 2006). This reconfiguration of the global ice-volume budget may have been associated with changes in deep-ocean circulation on glacial-interglacial (G-IG) (orbital) and shorter timescales (suborbital) (Raymo et al. 1997; Venz et al. 1999; Kleiven et al. 2003, 2011; Raymo et al. 2004; Hodell et al. 2008; Ferretti et al. 2010). During these events, ventilation by northern source waters was reduced at depths $>2500$ meters in the North Atlantic, in part because of the melting of icebergs and low-salinity surface waters released to the ocean during episodic surges of icebergs to North Atlantic (Broecker et al. 1992; Alley \& MacAyeal 1994; Broecker 1994). Results by Venz et al. (1999) showed that 
during the past 1.0 Myr, convection in the Greenland, Iceland, and Norwegian (GIN) Seas moved south of the Arctic Front (AF), and switched from a deep to an intermediate mode (Glacial North Atlantic Intermediate Water, -GNAIW-) during glacials. During most isotopic Terminations, melting of icebergs and production of low-salinity surface waters caused formation of the intermediate water mass to cease, resulting in decreased ventilation at all depths in the northern North Atlantic.

A strong linkage exists between changes in surface oceanography and decreased ventilation in the North Atlantic. Because deep convection in the GIN Seas depends on northward advection of heat through warm and saline Atlantic waters (Broecker 1991), studies using surface-ocean proxies (e.g. planktonic fauna and stable isotopes on planktonic foraminifera) may provide valuable information to understand changes in the deep ocean. Micropaleontological records and sea surface temperature (SST) reconstructions from the North Atlantic show major variations in composition and structure of planktonic assemblages throughout the MPT, related to severe cold surface waters events associated with the ice-sheet expansion and IRD discharge events which resulted in stagnation of deep North Atlantic waters (Wright \& Flower 2002; Reid et al. 2007; Marino et al. 2008, 2011; McClymont et al. 2008; Shimada et al. 2008). Although data exist for a wide range of organisms, we focus here mainly on planktonic foraminifera.

Because planktonic foraminifera offer multiple approaches to reconstruct surface ocean conditions (changes in assemblage, diversity, variations size and morphology, etc.), it has been frequently used as a tracer of North Atlantic water masses (e.g. Stehli 1965; Ruddiman 1969, 1989; McIntyre et al. 1972; Balsam \& Flessa 1978; Bauch 1994; Johannessen et al. 1994; Fronval et al. 1998; Wright \& Flower 2002; Kandiano et al. 2004), and especially to monitor changes in the position of the AF, which marks the southward extent of cold arctic waters and also sea-ice (Swift \& Aagaard 1981). Planktonic foraminifera can also provide insight into deeper conditions of the water column via the isotopic 
composition of some relatively deep-dwelling species. An example is the polar species $N$. pachyderma sin., which has been demonstrated to reflect conditions along the pycnocline (Bé \& Tolderlund 1971; Carstens \& Wefer 1992; Wu \& Hillaire-Marcel 1994; Kohfeld et al. 1996). Several recent studies in the Labrador Sea (western North Atlantic) have reconstructed the conditions at the upper-part of the of the intermediate water layer from the isotopic composition of N. pachyderma sin. (Hillaire-Marcel \& Bilodeau 2000; Hillaire-Marcel et al. 2001a; de Vernal et al. 2002; 2011).

In this paper, we use new high-resolution planktonic foraminifera assemblage data, $\delta^{13} \mathrm{C}$ of $N$. pachyderma sin., Shannon-Weaver diversity index and percentage of $\mathrm{CaCO}_{3}$ from Integrated Ocean Drilling Program (IODP) Site U1314 between 1069 and 779 ka, to obtain information of past sea-surface hydrological parameters. We examine the response of planktonic foraminifera species to palaeoenvironmental variations during the MPT, with special emphasis on the interrelations between environment and the palaeoecology of poorly known encrusted morphotype of $N$. pachyderma sin., and its potential as a valuable climatic index. Data are compared with available $\mathrm{CaCO}_{3}$ content and planktonic foraminifera records from neighbouring sites in the subpolar North Atlantic to monitor the AF oscillations and implications for the heat and moisture transport to the boreal ice-sheet regions. Finally, we examine the potential of the $\delta^{13} \mathrm{C}$ signal from $N$. pachyderma sin. as an intermediate water circulation proxy in the subpolar North Atlantic. The aim of this study increase the geographic coverage of proxy records for a better interpretation of temporal and spatial paleoceanographic changes in the subpolar North Atlantic during the MPT.

\section{Study area and site location}

IODP Site U1314 was drilled by the D/V JOIDES Resolution in the southern Gardar Drift, in the northeast Atlantic $\left(56.36^{\circ} \mathrm{N}, 27.88^{\circ} \mathrm{W}\right)$ during IODP Expedition 306 (Fig. 1). Due to its 
proximity to the "ice-rafted debris" (IRD) belt (Ruddiman 1977) Site U1314 (2820 m water depth) provides direct evidence of ice rafting activity from the Upper Pliocene to Holocene (Channell et al. 2006). Site U1314 is strongly influenced today by the northward flow of the North Atlantic Current (NAC). This surface water mass travels northward across the North Atlantic where it crosses the Mid-Atlantic Ridge between $53^{\circ} \mathrm{N}$ and $60^{\circ} \mathrm{N}$. One branch turns northwestwards and travels as the Irminger Current (IC) on the western and northern side of Iceland, while the main branch flows over the Iceland-Faeroe Ridge into the GIN Seas (Krauss 1986; Reynaud et al. 1995). This current carries heat to the north and maintains the warm climates of central and northern Europe. The northward flowing water is cooled in the Greenland-Iceland-Norwegian (GIN) Seas, increasing its density. Winter convection of the cooled Atlantic surface waters results in the formation of North Atlantic Deep Water (NADW) which flows as the Iceland-Scotland Overflow Water (ISOW) through the Faeroe Bank channel to enter the Iceland basin (Swift 1984; Schmitz \& McCartney 1993). The intermediate water masses in the eastern North Atlantic $(\sim 500$ to $\sim 2000 \mathrm{~m})$ that are characterized by extrema in salinity or potential temperature are Subarctic Intermediate Water, Mediterranean Sea Outflow Water, and Labrador Sea Water; at low latitudes Antarctic Intermediate Water can also be recognized from a salinity minimum (van Aken 2000; Álvarez et al. 2004).

Site U1314 is seasonally affected by the southward extension of cold and less saline waters of the East Greenland Current (EGC). The distinct oceanic front between warm saline NAC and the IC, and the cold arctic waters, is known as the Arctic Front (AF). The AF marks the maximum extent of winter sea-ice. The cold and low salinity polar waters transported by the EGC are separated from the cold but saltier arctic waters by the Polar Front (PF) (Swift \& Aagaard 1981). The PF is close to the summer sea-ice edge, thus polar waters are perennially under the sea-ice cover, resulting in minimal carbonate productivity (Henrich 1998). South of 
the $\mathrm{AF}$, calcareous productivity is more intense, while terrigenous deposition occurs widely north of the AF (Henrich et al. 2002).

\section{Material and methods}

The sedimentary sequence recovered at this Site U1314 varies in color from very dark grey to light grey to hues of greenish grey, and consists mainly of predominantly nannofossil oozes enriched in biogenic and terrigenous components, and terrigenous silty clay with a varying proportion of calcareous (e.g., nannofossils, foraminifers) and siliceous organisms (e.g., diatoms and radiolarians). More detailed core descriptions are in (Channell et al. 2006).

Samples were taken every $4 \mathrm{~cm}$ as 2 -cm thick slices between the 60 to 84.16 meters composite depth (mcd). Each sample was oven-dried, weighed, and wet sieved over a $63 \mu \mathrm{m}$ screen, and then oven-dried again. Later, samples were dry sieved into two fractions, 63-150 $\mu \mathrm{m}$ and $>150 \mu \mathrm{m}$. Census counts and picking for the stable isotope analyses were carried out in the $>150 \mu \mathrm{m}$ fraction. Full census counts were completed every other sample (total 325 samples), with and average resolution of $\sim 0.9 \mathrm{ka}$ (see Chronology and age-depth modeling section). Each sample was split as many times as necessary to obtain an aliquot that contains about 400 planktonic foraminifers, then species of planktonic and benthic foraminifera, mineral grains, ash, lithic fragments, radiolarians, ostracodes and planktonic foraminifera fragments were counted and relative abundances and fluxes were then calculated. Our taxonomy criteria for planktonic foraminifera specimens follows that of Bé (1977) and Hemleben et al. (1989). Diversity patterns of planktonic foraminifera assemblage were determined using the Shannon Weaver diversity index (Shannon \& Weaver 1963), given by the following equation:

$$
H=-\sum_{\mathrm{i}=1}^{\mathrm{s}}\left(p_{\mathrm{i}} \ln p_{\mathrm{i}}\right)
$$


where $\mathrm{H}$ is the Shannon Weaver diversity index, $p_{\mathrm{i}}$ is the fraction of the entire population made up of species $1, \mathrm{~s}$ is the number of species encountered, and $\sum$ the sum from species 1 to species S. This index is sensitive to both changes in the number of species and their relative abundance in the sample. High values can result from an addition of species, greater equality in abundance, or both. In modern Atlantic Ocean, planktonic foraminifera diversity shows a strong correlation with SST. Polar waters of both hemispheres show lowest diversity, being dominated by a single species (N. pachyderma), while the highest diversity and largest sizes are found in the oligotrophic subtropical gyres (Rutherford et al. 1999). A more detailed discussion of this index and its use in ecological studies is provided by (Pielou 1975).

The total carbon (TC) content of the sediment was measured in 584 samples using a UIC Coulometrics CM150 carbon analyzer. For total organic carbon (TOC) analyses, first we removed total inorganic carbon (TIC) following standard procedures (Van Iperen \& Helder 1985). About $0.2 \mathrm{~g}$ of powdered sample was digested in $2 \mathrm{~N} \mathrm{HCl}$ in $50 \mathrm{ml}$ centrifuge tubes, and shaken by hand periodically until carbonate reaction was no longer visible. The samples were dried overnight at $\sim 70^{\circ} \mathrm{C}$ to evaporate excess $\mathrm{HCl}$. In order to ensure all $\mathrm{HCl}$ was removed samples were rinsed with deionized water, and then centrifuged and decanted. After two rounds, wet sediment was transferred to a vial and dried overnight at $65^{\circ} \mathrm{C}$. TOC was then measured using a Flash 2000 Combustion CHNS/O Analyzer.

TIC and $\mathrm{CaCO}_{3}$ were then calculated from the weight percentages of the TC and TOC using the following equations:

$$
\begin{gathered}
\mathrm{TIC}=[(\mathrm{TC}-\mathrm{TOC} / 100) /(1-(\mathrm{TOC} / 100) \cdot 8.33)] \cdot 100 \\
\mathrm{CaCO}_{3} \%=\mathrm{TIC} \cdot 8.33
\end{gathered}
$$


The accumulation rates of planktonic foraminifera $(\mathrm{PF} \mathrm{AR}=$ Planktonic Foraminifera Accumulation Rate) to estimate surface productivity was calculated using the following equation:

$$
\mathrm{PF} \mathrm{AR}=\text { planktonic foraminifera concentration } \cdot \mathrm{MAR}
$$

where $\mathrm{PF}$ AR is given in number of individuals $\mathrm{cm}^{-2} \mathrm{ka}^{-1}$; planktonic foraminifera concentration (number of individuals $\left.\mathrm{g}^{-1}\right) ; \mathrm{MAR}=$ mass accumulation rates $\left(\mathrm{g} \mathrm{cm}^{-2} \mathrm{ka}^{-1}\right)$ $\left(\mathrm{MAR}=\mathrm{SR} \cdot \mathrm{DBD} ; \mathrm{SR}=\right.$ sedimentation rate $\left(\mathrm{cm} \mathrm{ka}^{-1}\right) ; \mathrm{DBD}=\operatorname{dry}$ bulk density $\left(\mathrm{g} \mathrm{cm}^{-3}\right) . \mathrm{SR}$ and DBD are published in Hernandez Almeida et al. (2012) and IODP-USIO Janus web database (2007), respectively.

In order to estimate carbonate dissolution, a planktonic foraminifera fragmentation index (FI) was also calculated by measuring the ratio between planktonic foraminifera fragments and whole tests. Furthermore we estimate the ratio of benthic to planktonic foraminifers $\mathrm{B} /(\mathrm{P}+\mathrm{B})$ in the $>150 \mu \mathrm{m}$ size fraction. In general, dissolution produces more planktonic foraminifera fragments and preferentially removes planktonic foraminifers, which leads to a higher $\mathrm{FI}$ and $\mathrm{B} /(\mathrm{P}+\mathrm{B})$ ratio (Thunell 1976).

The benthic and planktonic stable isotope records were previously published by to Hernández-Almeida et al. (2012). One to eight tests of Cibicidoides spp. (mainly $C$. wuellerstorfi and occasionally $C$. pachyderma) were picked from the $>250 \mu \mathrm{m}$ size fraction and one to eight individuals were used for isotopic analysis. When this species was absent, we picked specimens of Melonis pompilioides from the same size fraction to produce a continuous signal. In order to elaborate a homogenous isotope record from both species, we calculated the mean difference between both species in 74 samples covering the 1069 to 400 ka period (this study; Alonso-Garcia et al. 2011). The average difference was used to adjust both records, $-0.11 \%$ for the oxygen and $+0.6 \%$ for the carbon isotopes.

For the planktonic foraminifera stable isotope study, we chose to analyse Neogloboquadrina pachyderma sinistral (sin.), because this species is present throughout the 
studied section. A minimum of 15 specimens from the size range between 150-250 $\mu \mathrm{m}$ were picked. Benthic and planktonic specimens of each sample were crushed, ultrasonicated and cleaned with methanol before the isotopic analyses. Benthic and planktonic foraminifera stable isotope analyses were carried out in a Finnigan MAT 252 mass spectrometer at the University of Barcelona. Calibration to the Vienna Pee Dee Belemnite (VPDB) standard scale (Coplen 1996) was made through the NBS-19 standard, and the analytical precision was better than $0.06 \%$ for $\delta^{18} \mathrm{O}$ and $0.02 \%$ for $\delta^{13} \mathrm{C}$.

Since $\delta^{13} \mathrm{C}$ values measured in planktonic foraminifera tests are related to nutrient concentrations (Broecker \& Peng 1982), the analyses of carbon isotopes in N. pachyderma sin. aims to reconstruct the structure of the bottom of the pycnocline (the upper-part of the intermediate water layer). To test the potential of $N$. pachyderma $\sin . \delta^{13} \mathrm{C}$ as a tracer of intermediate ventilation, we compared our record to benthic $\delta^{13} \mathrm{C}$ data from Site 982, which is bathed by the well ventilated GNAIW during glacial stages between 0-1.0 Ma (Venz et al. 1999) The $\sim 0.9 \%$ off-set between benthic and planktonic $\delta^{13} \mathrm{C}$ records from Site 982 and U1314 represents the metabolic and vital effects of $\delta^{13} \mathrm{C}$ values of $N$. pachyderma sin. These are well constrained by a shift of $+0.9 \%$ versus $\delta^{13} \mathrm{C}$ in dissolved inorganic carbon (DIC) (Labeyrie \& Duplessy 1985). At the level of the pycnocline (upper-part of the intermediate layer), where N. pachyderma sin. lives (e.g. Bé \& Tolderlund 1971; Simstich et al. 2003), the sea water $\delta^{13} \mathrm{C}$ is already partially affected by addition of $\mathrm{CO}_{2}$ with low ${ }^{13} \mathrm{C}$, recycled from settling organic matter (Kroopnick 1985). To facilitate comparison with the ODP Site 982 (1145 m depth) benthic $\delta^{13} \mathrm{C}$ record, our $N$. pachyderma $\sin . \delta^{13} \mathrm{C}$ record was adjusted to a 'Cibicidoides' scale by adding +0.9\%o (Labeyrie \& Duplessy 1985).

Finally, we compared our records with other available proxies at ODP Sites 982 $\left(\mathrm{CaCO}_{3}\right.$, IRD) (Baumann \& Huber 1999; Venz et al. 1999) and 983, 980 and $984\left(\mathrm{CaCO}_{3}\right.$, planktonic foraminifera assemblages) (Ortiz et al. 1999; Wright \& Flower 2002) in order to provide a regional perspective of paleoceanographic changes in the subpolar North Atlantic. 
Benthic $\delta^{18} \mathrm{O}$ records from former sites were used to correlate these records to the LR04 benthic $\delta^{18} \mathrm{O}$ stack, and thus the Site U1314 age.

\section{Notes on taxonomy of Neogloboquadrina pachyderma sinistral}

Microscopic investigation of planktonic foraminifera for quantitative analyses was conducted under light microscope, but we also performed visual inspection of the specimens using SEM microscope in order to make a morphotype separation. In our samples, we clearly distinguished the two different coiling directions of N. pachyderma, dextral and sinistral (Fig. 2A, B, M; C, D, N, respectively). Within the sinistral coiling, we identified two morphotypes on the basis of the criteria of Srinivasan \& Kennett (1974) and Vilks (1974). The two morphotypes are characterized as (i) nonencrusted $N$. pachyderma sin. with a smooth, shiny, reticulate surface, and with larger latter chambers and lobate shape (Fig. 2C, D), and (ii) encrusted morphotype with tiny and compact chambers, with an opaque and quadrate shell, and with a heavily encrusted crystalline surface (Fig. 2E-L, O-P). These morphotypes are close to those that are recognized in North Atlantic and Arctic sediments (Eynaud et al. 2009; Moller et al. 2011). At Site U1314, encrusted individuals of $N$. pachyderma sin. appear more abundant during the last two glacial stages, at MIS 22 and 20, replacing the lobate form of this species (Fig. 3A;B). Large numbers of the encrusted morphotypes of $N$. pachyderma sin. first appear close to the Plio/Pleistocene boundary, in conjunction with the deposition of glacial detritus and the absence of other cold water species, such as $N$. atlantica and nonencrusted $N$. pachyderma sin. (Poore \& Berggren 1975; Huddlestun 1984). It is unclear whether this encrusted form results from a process that converts nonecrusted $N$. pachyderma sin. into encrusted morphotypes by a secondary calcification that takes place below critical water depths (Bé 1960; Kohfeld et al. 1996; Volkmann \& Mensch 2001), or if they are indeed different morphotypes entirely (Bergami et al. 2009). What is clear is they occupy two distinct environments. The nonencrusted morphotype are found in the mixed layer, between 
100-150 m, above the main pycnocline, whereas the encrusted morphotypes are associated to greaterdepths up to 300 m, within the main pycnocline (Kohfeld et al. 1996; Stangeew 2001; Bergami et al. 2009).

\section{Chronology and age-depth modelling}

The conversion from core depth to time was derived by direct correlation of benthic foraminifera oxygen isotope record from Site U1314 and the LR04 benthic isotope stack (Lisiecki \& Raymo 2005). All correlations were performed using the AnalySeries 2.0software (Paillard \& Yiou 1996). The final age model for the $24.16 \mathrm{~m}$ studied section spans an interval of $290 \mathrm{ka}$ (1069 to $779 \mathrm{ka}$ ) through the early and mid-Pleistocene based on 13 stratigraphic tie points, yielding a temporal resolution of 547 years for the full resolution records and 1094 years for the every other sample records. Between tie points sedimentation rates were assumed constant based on shipboard preliminary stratigraphy (Channell et al. 2006). The resulting sedimentation rates are moderately high (average $9.3 \mathrm{~cm} \mathrm{ka}^{-1}$ ) and differ largely between glacial (as low as $1.15 \mathrm{~cm} \mathrm{ka}^{-1}$ ) and interglacial (up to $27 \mathrm{~cm} \mathrm{ka}^{-1}$ ) intervals, which is a consistent feature in the area of the Gardar Drift (Huizhong \& McCave 1990; Dickson \& Brown 1994). The variability of sedimentation rates can be attributed to changes in the intensity of the ISOW (Bianchi \& McCave 2000). Further details of the age model construction can be found in Hernández-Almeida et al. (2012). Isotopic events labeled at Site U1314 records $(30.1,29.1,27.1,24.1,23.3,23.1,21.7,21.5,21.3$ and 21.1) correspond to nomenclature given to suborbital-scale climate events observed in the benthic $\delta^{18} \mathrm{O}$ record from Site U1314 by Hernandez-Almeida et al. (2012).

\section{Results}




\section{Fauna}

The most abundant foraminifera species are Neogloboquadrina pahyderma sin., Neogloboquadrina pachyderma dextral (dex.), Globorotalia inflata, Globigerina bulloides, Globigerinita glutinata and Turborotalita quinqueloba. Glacial stages are highly dominated by $N$. pachyderma sin., while interglacial stages comprise a multispecies assemblage, where N. pachyderma dex. is the most abundant (from $65 \%$ to less than $1 \%$, average $20 \%$ ), followed by G. inflata, and secondarily, G. bulloides, T. quinqueloba and G. glutinata (Fig. 4). N. pachyderma sin. shows a high variability ranging from 5 to $90 \%$ (average $60 \%$ ). The lowest values are recorded at MIS 19, while high values are observed during glacial stages (Fig. 4A). The N. pachyderma dex. distribution pattern is opposite to that of the sinistral coiling variety, with higher abundances during interglacial stages MIS 25, 21 and 19 (Fig. 4B).

The abundance record of $G$. inflata is similar to that of $N$. pachyderma dex., with values between 40 and $0 \%$ (average $8 \%$ ), with a prominent peak during MIS 25. However, both species display opposite trends during MIS 21 (Fig. 4C). The relative abundance of $G$. bulloides varies between 0 and 25\% (average 6\%), reaching the maximum values during MIS 21. The pattern shown by this species is similar to that of $N$. pachyderma dex., except during MIS 25 and 21, where they show rather opposite trends (Fig. 4D).

Besides the most abundant species described previously T. quinqueloba and $G$. glutinata contributed in lower proportion to the total assemblage. T. quinqueloba percentages are below 5\% (average 2\%) throughout the studied section, except at MIS 29 and 21, when percentages reach 18\% (Fig. 4E). The G. glutinata distribution resembles that of G. bulloides; with values between 0 and $8 \%$ (average 2\%). The main feature of this curve are the low values from MIS 22 upward, and the abrupt increase from MIS 23 downward, where three peaks of around $8 \%$ occur (Fig. $4 \mathrm{~F})$.

\section{$\delta^{13}$ C record from Neogloboquadrina pachyderma sin.}


The N. pachyderma sin. $\delta^{13} \mathrm{C}$ record of Site U1314 shows a pattern of lower values during the late glacial and deglacial phase and higher values during the later phase of the interglacial and during glacials (Fig. 5C). Higher values are recorded before MIS 25, with a peak maximum during MIS 27, at 988 ka. Values decreased in average between the MIS 24-19 interval, recording pronounced $\delta^{13} \mathrm{C}$ minima at Terminations 24/23, 22/21 and 20/19, coinciding with greater IRD events at Site U1314 (Hernández-Almeida et al. 2012).

\section{Distribution of total planktonic foraminifera concentration, carbonate content and}

\section{diversity index}

The $\mathrm{CaCO}_{3}$ values from Site U1314 averaged 34.3\%, with higher carbonate concentrations occurring in interglacial isotope stages and lower concentrations in glacial stages (Fig. 6A). The typical glacial-to-interglacial change in carbonate percentage over the 1069-779 ka time period was from 8 to $50 \%$, within in the range of the distribution of $\mathrm{CaCO}_{3} \%$ in surface sediments in this region and during the Last Glacial Maximum (LGM) (Biscaye et al. 1976; Bianchi \& McCave 2000). Highest values occurred during interglacial stage 31, 25, 21 and 19 , and lowest during glacial stage 28, 26 and 22.

High PF AR are recorded late in the interglacial phase of MIS 27, 25 and 20, where the largest peak was recorded (798 ka) (Fig. 6B). The PF AR are generally within the range of the published data from Holocene sediment cores collected in the same area, $\sim 15 \times 10^{4}$ individuals $\mathrm{cm}^{-2} \mathrm{ka}^{-1}$ (Rasmussen et al. 2003b), except for the aforementioned maxima at MIS 20. In terms of species, N. pachyderma sin. is the major contributor to the PF productivity (Fig. 6C), while other subpolar species appear to be more important during interglacial stages (Fig. 6D), temporal pattern similar to that observed for $\mathrm{CaCO}_{3}$ content.

Changes in $\mathrm{CaCO}_{3}$ percentages and PF AR may also be influenced by dissolution, which has to be taken into account for all palaeoenvironmental interpretations based on these proxies. To estimate variations in carbonate dissolution we used the planktonic fragmentation 
index (FI). Higher FI values take place with higher percentages of N. pachyderma dex., G. inflata, G. bulloides and T. quinqueloba, while it decreases at times of dominance of the polar species N. pachyderma sin., with a maximum FI of $32 \%$ at 1002 ka (Fig. 6E). Overall, this index is generally lower than $40 \%$, the level at which planktonic foraminifera assemblages are determined to be altered by dissolution (Miao et al. 1994). The low FI value found for Site U1314 indicates good $\mathrm{CaCO}_{3}$ preservation, with no significant differences between glacial and interglacial stages. This assumption is plausible since Site U1314 is bathed by oxygenrich, dense deep-water from the GIN Seas, which are supersaturated with respect to carbonate ion, and it is located above the aragonite compensation depth which is presently about $3300 \mathrm{~m}$ in the North Atlantic (Broecker \& Takahashi 1978). In addition, the $\mathrm{B} /(\mathrm{P}+\mathrm{B})$ ratio was $<<1$, which suggests that extensive calcium carbonate dissolution did not take place in the subpolar North Atlantic between MIS 31 and 19 (Fig. 6F).

The Shannon diversity $(H)$ index follows the record of subpolar, temperate-water species, with higher diversity in the planktonic foraminifera assemblage during interglacial and lower during glacial stages (Fig. 3C). The highest diversity is found during MIS 30, 25 and 21, and lowest diversity is recorded during glacial maximum at MIS 22 and MIS 20.

\section{Discussion}

\section{North Atlantic paleoceanography and palaeoproductivity}

The present distribution of planktonic foraminifera assemblages reflects the general hydrography of the modern North Atlantic. High percentages of N. pachyderma sin. are associated with the EGC, with annual mean temperatures of $2^{\circ} \mathrm{C}$ (Tolderlund \& $\mathrm{Be} 1971$; Pflaumann et al. 2003), and occurs in a wide range of habitats including sea ice (Spindler \& Dieckmann 1986). In contrast, N. pachyderma dex. and G. inflata are definitely linked to the warmer waters of the NAC (Kipp 1976; Schiebel \& Hemleben 2000; Hald et al. 2007). Other 
species such as G. bulloides, G. glutinata and T. quinqueloba are also present, the latter species being more abundant along the region of the AF (Johannessen et al. 1994). Site U1314 is located today along the main course of the NAC, and a foraminifera assemblage dominated by N. pachyderma dex. G. inflata, G. glutinata and G. bulloides, with almost no N. pachyderma sin. (Schiebel \& Hemleben 2000; Hald et al. 2007).

Between MIS 31 and 26, surface arctic waters dominated this region, as indicated by the high percentages of $N$. pachyderma $\sin .(\sim 90 \%)$, which were cyclically replaced by temperate Atlantic waters. Interglacial conditions similar to those found today in this region were not reached until MIS 25, when N. pachyderma dex. + G. inflata surpassed 70\% (Andersson et al. 2009; Chapman 2010) (Fig. 4A-C), revealing a penetration of Atlantic waters after this interglacial stage. Decreasing percentages of the only polar species found at Site U1314, N. pachyderma sin., indicate a north-west retreat of the AF and rising SST. These AF retreats were moderate prior MIS 25, since $N$. pachyderma sin. abundances did not fall below $40 \%$ within this period. Hence, we can infer a limited influence of the NAC at this latitude compared to today, since relative abundances of this polar species in modern pelagic sediments are below 10\% (Andersson et al. 2009; Chapman 2010). Diatom assemblage records from North Atlantic IODP Sites 983 and 1304 support this interpretation, since they were dominated by the cool and low-saline waters Neodenticula seminae during this period (Koç et al. 1999; Shimada et al. 2008), reflecting a more southerly extension of the AF than today (even during interglacials). Southern limits of the AF may have reached latitudes between $32-37^{\circ} \mathrm{N}$, based on the occurrence of the diatom $N$. seminae in North Atlantic sediments (Baldauf 1986; Ikeda et al. 2000). Cooler surface waters during glacial stages were not suitable for high surface productivity levels, as seen in the decrease in $\mathrm{CaCO}_{3}$ values $(2 \%)$ during MIS 28 and 26, a condition likely due to southeastward migration of the PF, covering U1314 with year-round sea ice cover (Fig. 6A). In contrast, during MIS $30 \mathrm{CaCO}_{3}$ values between $7-30 \%$ at Site U1314 and the presence of diatom productivity at the neighboring Site 
983 (Koç et al. 1999) reflects some degree of surface productivity, and suggests that the North Atlantic was free of sea-ice during this glacial stage.

In a similar way to the two 'eccentricity-like' cycles recognized in the benthic $\delta^{18} \mathrm{O}$ record by Hernández-Almeida et al. (2012) (Fig. 5A), planktonic foraminifera assemblages changed at the onset of interglacial cycle of MIS 25based on the N. pachyderma and G. inflata record (Fig. 5B, dashed line), two 100-ka cycles can be recognized. The first 100-ka G-IG cycles occur at c. $950 \mathrm{ka}$ (MIS 25 to 22), and started with high percentages of $N$. pachyderma dex. + G. inflata. These values reached well over $70 \%$, very similar to those found during the Holocene and indicating a SST between 10 and $14^{\circ} \mathrm{C}$ (Pflaumann et al. 2003; Hald et al. 2007), and indicating a long period of $20 \mathrm{ka}$ of warm-water advection to Site U1314. This warming was followed by a sharp cooling event, evidenced by a pronounced increase in abundance of $N$. pachyderma sin. up to $93 \%$ (Fig. 3B, solid line). This event took place at $933 \mathrm{ka}$ and reflects an abrupt southward shift of the AF. Cool arctic conditions were followed by three events of significant NAC advection towards the North Atlantic. The first one, of smaller amplitude, occurred during substage 24.1 , while the later two related with warmer waters are linked to substages 23.1 and 23.3. Maximum glacial conditions during this 100-ka cycle were recorded during MIS 22 in which arctic waters with planktonic foraminifera assemblage characterized by $94 \%$ N. pachyderma sin. dominated in the region for a long period of time, spanning from 885 to $862 \mathrm{ka}$ (Fig. 5B, solid line). This glacial stage is considered the first of the major cold events that typify glaciations of the Late Pleistocene and the most severe of the early and mid-Pleistocene (Head \& Gibbard 2005). Based on the high benthic $\delta^{18} \mathrm{O}$ values (Fig. 5A), and on the diatom-barren samples at Site 983 (Koç et al. 1999), we infer that the PF may have migrated southeastward, bringing extremely low SST and perennial sea-ice conditions to the subpolar North Atlantic.

The second 100-ka cycle started with an abrupt warming event at the onset of MIS 21 at c. 860 ka (MIS 21 to 19), when waters with dominant $N$. pachyderma sin. were rapidly 
replaced by waters with abundant $N$. pachyderma dex. + G. inflata (Fig. 5B). These remained as the dominant species until $845 \mathrm{ka}$, when an abrupt southward advance of the AF took place with the subsequent proliferation of $N$. pachyderma sin., marking the onset of substage MIS 21.5. This marked the beginning of a long-term period of ice-sheet growth towards the glacial maximum recorded at around $800 \mathrm{ka}$. However, a series of suborbital scale North Atlantic oscillations are recorded by the planktonic foraminifera assemblages that, in general, follow the isotope substages recognized during MIS 21. These were interpreted by Ferretti et al. (2010) as harmonics of the precession cycles. Events of enhanced northward advection of the NAC are recorded during isotope substages 21.5, two events in substage 21.3, of which the latest one is very prominent, and a low amplitude event in substage 21.1, which indicates strong advection of the NAC towards the North Atlantic latitudes, similarly to that occurring today in this region. Higher $\mathrm{CaCO}_{3}$ values during these substages support the inferred retreat of the AF, allowing more NAC waters to bath latitudes over $60^{\circ} \mathrm{N}$ (Fig. 6A). This finding is substantiated by the concomitant increase in $\mathrm{CaCO}_{3} \%$ in several sites from the GIN Seas (Henrich 1989; Henrich \& Baumann 1994), which also reflected an increased surface water exchange between North Atlantic and Norwegian basins. Fully glacial conditions, with a planktonic foraminifera assemblage dominated by $N$. pachyderma sin., prevailed from 815 to $790 \mathrm{ka}$ (MIS 20), with only a short incursion of warm-water species at around $815 \mathrm{ka}$. The presence of significant diatom production at sites 919 and 983 (Koç \& Flower 1998; Koç et al. 1999), and $\mathrm{CaCO}_{3}$ percentages of $17 \%$ during MIS 20, indicate at least seasonally open marine conditions and a PF north of $60^{\circ} \mathrm{N}$ during this time.

Besides major changes in planktonic foraminifera assemblage at G-IG and suborbital time-scales, there are striking ecological successions within warm intervals and fauna changes along the studied section that can indicate changes in the properties of surface waters. $N$. pachyderma dex. reaches its maxima modern representation in the North Atlantic with enhanced warm NAC advection, especially toward longitudes $>0^{\circ} \mathrm{E}$, with warm, stratified 
surface waters during summer (Sautter \& Thunell 1989; Schiebel \& Hemleben 2000; Bauch \& Kandiano 2007; Fraile et al. 2008). In contrast, although G. bulloides and G. glutinata also occupy the upper meters of the water column, their seasonal peak abundance seems to differ from these other groups, occurring today during spring at $60^{\circ} \mathrm{N}$ following phytoplankton blooms during ice-free periods (Bé 1977; Schiebel \& Hemleben 2000; Schiebel et al. 2001; Fraile et al. 2008). Accordingly, a decrease of $N$. pachyderma dex. after interglacial maxima at Site U1314 indicates an eastward shift in the flow path of the NAC toward the Norwegian continental margin, and an incipient expansion of colder waters during late interglacial periods (e.g., at MIS 25 and 21.1; Fig. 4B). Higher G. bulloides and G. glutinata levels during this progressive cooling might represent wind driven mixing and peaks of chlorophyll in open ocean conditions, suggesting that nutrient content played a more important role than temperature for this species (Fig. 4D, F).

Regional warming as a consequence of a greater retreat of AF at MIS 21 may have affected G. glutinata, whose percentages are considerably higher during interglacial stages before MIS 22 than after (Fig. 4F). This species is not as opportunistic as G. bulloides, and is more specifically adapted to a diatom-based diet (Hemleben et al. 1989; Schiebel \& Hemleben 2000). Since the period before MIS 22 is characterized by a diatom fauna dominated by $N$. seminae, a major component in prominent spring blooms in the subarctic ocean (Reid et al. 2007), it is possible that disappearance of this diatom was caused by regional warming of the North Atlantic after MIS 22. Latitudinal migration of the AF, resulted in accelerated dumping of large diatoms during advances of warm waters (Koç et al. 1999; Shimada et al. 2008). This in turn may have diminished the main food source for $G$. glutinata, leading to a decrease in its percentages after MIS 22.

G. inflata has been correlated to the IC at the subpolar North Atlantic (Olson \& Smart 2004; Chapman 2010), which results from a mixture of Irminger Sea water and the warmer and saltier water transported by the NAC (Reynaud et al. 1995). As G. inflata accounts only 
for $\sim 12 \%$ of total in the modern North Atlantic at around $49^{\circ} \mathrm{N}$, and $\sim 2 \%$ in core top fauna at $60^{\circ} \mathrm{N}$ (Chapman 2010), the observed peaks of this species in excess of $25 \%$ at 946,902 and 849 ka imply a markedly different palaeoenvironment (Fig. 4C). Thus, it is possible that its proliferation was linked to strong phases of IC advection and a well-mixed environment, with potentially lower nutrient levels and warmer temperatures than during peaks of G. bulloides.

Higher T. quinqueloba percentages generally occur at Site U1314 between peaks of $N$. pachyderma dex. and $N$. pachyderma sin., but in relatively low abundances, revealing a shift from temperate Atlantic waters to cool subpolar water masses (Fig. 4E). This species is usually associated with the proximity of the AF (Hebbeln et al. 1994; Johannessen et al. 1994), and thus can be interpreted as a proxy for the AF swings. Values below $2 \%$ on average during the MIS 31-19 interval reflect the almost steady position of the AF far from the Site U1314, with only the exceptions of increased T. quinqueloba percentages at MIS 21 substages, indicating that the AF moved back closer to the Site U1314 position.

Overall changes in the $\mathrm{CaCO}_{3}$ content and PF AR at Site U1314 are decoupled along the 1069-779 ka interval (Fig. 6A;B). This pattern suggests that planktonic foraminifers were a secondary component of biogenic carbonate at least in the early interglacial phases, corroborating other studies that determined that coccolithophores were the main contributors to $\mathrm{CaCO}_{3}$ content in the Northeast Atlantic (van Kreveld et al. 1996; Baumann \& Huber 1999). During late interglacial phases and glacial stages, a southward migration of the AF and concomitant expansion of the EGC occurred which shifted the NAC towards the south. Under this scenario, carbonate from primary producers (coccolithophores) was reduced (Balestra et al. 2010), while polar foraminifera N. pachyderma sin. found optimal environmental conditions. Except for the short glacial peaks of the cold water-adapted coccolithophore $C$. pelagicus at sites 980 and 982 (Baumann \& Huber 1999; Marino et al. 2011), there was no other polar-adapted carbonate secreting species and thus carbonate accumulation in the subpolar North Atlantic during glacials was limited to N. pachyderma sin. (Fig. 6C). In 
contrast, northward migration of the AF and the flow of the warmer waters favored coccolithophore bioproductivity and increased accumulation of subpolar planktonic foraminifera species (Fig. 6D) (Baumann \& Huber 1999; Marino et al. 2011). Additionally, deep-ocean currents favored the lateral transport of particles settling in the water column all over this region of the North Atlantic that finally accumulated in the Gardar Drift. Besides changes in overall productivity and vertical settling, a reorganization of the bottom currents over the eastern North Atlantic could have influenced the $\mathrm{CaCO}_{3}$ distribution, and hence the concentration of planktonic foraminifera and $\mathrm{CaCO}_{3} \%$ in sediments across the Pleistocene (Huizhong \& McCave 1990; McCave et al. 1995; Bianchi \& McCave 2000).

\section{Progressive increase in abundance of the N. pachyderma sin. "encrusted" type and} changes in diversity of planktonic foraminifers

N. pachyderma sin. often dominates planktonic foraminifera assemblages of the northern North Atlantic, but shows a wide range of morphological variations (e.g. Cifelli 1973). In glacial periods prior to MIS 22, the abundance of the encrusted morphotype of N. pachyderma sin. was low, between 20 and 30\%. A significant increase in abundance was recorded in MIS 22 and MIS 20, which represent the glacial maximum periods of the two first 100-ka glacial cycles (Fig. 3A;B). Encrusted morphotypes are dominant in modern stratified waters with strong pycnocline in north and south high-latitude oceans (Kohfeld et al. 1996; Stangeew 2001; de Vernal et al. 2005; Bergami et al. 2009), and the occurrence of these larger specimens may be related to subsurface penetration of the Atlantic inflow (Hillaire-Marcel et al. 2004). These observations could explain size selection of $N$. pachyderma sin. specimens at Site U1314 and those from other high-latitude sites. Other factors influencing the observed mortphotype variability of $N$. pachyderma sin. may be selective dissolution or ontogeny. Dissolution is unlikely because there is low or nonexistent dissolution in the planktonic foraminifera assemblage throughout the intervals with high percentages of encrusted $N$. 
pachyderma sin., indicating that dominance of this morphotype is not controlled by this factor. Ontogeny does not seem a feasible explanation either, because the encrusted specimens had achieved full adult size and do not correspond to juvenile stages (Hemleben et al. 1989).

We suggest that size distribution of $N$. pachyderma sin. at Site U1314 is uniquely linked to pulsed Atlantic G-IG inflow, with large specimens calcifying during increased rates of subsurface penetration of the Atlantic waters and smaller ones occurring with more restricted environment along the pycnocline. These harsher conditions with lower SST and strong pycnocline were likely achieved during MIS 22 and 20, allowing N. pachyderma sin. encrusted morphotype to thrive at greater depths for a few thousand years at Site U1314. Intensification of the glacial cycles during the MPT caused an ecological adaptation of $N$. pachyderma sin., which after MIS 22 was mainly represented by the encrusted morphotype, reflecting a progressive polar water specialization in response to the onset of the $100-\mathrm{ka}$ climatic cycle that led to stronger glaciations (Fig. 3B). Similar conclusions were obtained by Kucera \& Kennett (2002) for the eastern North Pacific, who found a consistent pattern of encrusted and more compact N. pachyderma sin. populations after 990 ka. Hence, we argue that the temporal evolution of encrusted morphotypes of $N$. pachyderma sin. in fossil planktonic foraminifera assemblages and apparent hemispheric synchronicity represent a useful index for interpreting Pleistocene climates.

Diversity variations in a fossil planktonic foraminifera assemblages can also be used as a proxy for surface circulation, since variations of dominant ocean currents can affect habitat of the water column (Bé 1977; Jenkins 1993). Higher planktonic diversity in North Atlantic environments is associated with a well-established flow of the warm NAC (Ruddiman 1969; Balsam \& Flessa 1978). Intervals with relatively higher $H$ appear to correlate with increased advection of this warm Atlantic current during interglacial isotopic stages 31, 29, 27, 25, 23 and 21. Diversity declines marked by lower $H$ coincide with highest 
percentages of the $N$. pachyderma sin. encrusted morphotype at MIS 22 and 20 and heavier benthic $\delta^{18} \mathrm{O}$ values (Fig. $3 \mathrm{C}$ ). This indicates more severe glaciations and extreme low SST derived from the large build-up of the ice-sheets and cold surface waters with arctic origin reaching the Site U1314 location during these intervals. This conclusion is consistent with Hillaire-Marcel et al. (2004) and de Vernal et al. (2005), who report smaller N. pachyderma sin. specimens with more restricted environment and lower NAC inflow into the western North Atlantic. Moreover, similar fluctuation patterns of nannofossil diversities have been observed in other Atlantic sites (Sites 607 and 980/981), interpreted as due to a change in G-I periodicity from 40-ka to 100-ka (Marino et al. 2008; 2011) and indicating more intense glacial and interglacial phases.

\section{Intermediate circulation in the eastern North Atlantic}

A strong difference in the planktonic $\delta^{13} \mathrm{C}$ response is seen before and after MIS 25. Between MIS 31 and 25, planktonic $\delta^{13} \mathrm{C}$ values at Site U1314 are higher, and exhibit positive peaks during episodes with high percentages of $N$. pachyderma sin. and IRD events, related to a southward shift of the AF and ice-sheet advance/retreat sequences (Fig. 5B;C). These events had a low impact on the AMOC and some ventilation of intermediate waters was occurring throughout most of the glacial stages in the subpolar North Atlantic. Such an approach is supported by some convection during winter south of the AF, as depicted by the high benthic ${ }^{13} \mathrm{C}$ values at Site 982 (Venz et al. 1999). Increased $\delta^{13} \mathrm{C}$ values are also observed at the Rockall Plateau and Gardar Drift during the LGM and are interpreted to result from a shift in the convection cell from the Nordic Seas to the subpolar North Atlantic in a process analogous to that for the glacial production of Labrador Sea Water (Dowling \& McCave 1993; Oppo \& Lehman 1993).

After MIS 25, negative $\delta^{13} \mathrm{C}$ peaks lasting well into the subsequent interglacials are observed during Terminations at 24/23, 22/21 and 20/19, coinciding with lowest benthic $\delta^{13} \mathrm{C}$ 
and greatest IRD delivery at sites 982 and U1314 (Fig. 5C-E). This suggest decreased ventilation of the intermediate water mass in the northeast North Atlantic, as already demonstrated by several authors (Venz et al. 1999; Spero \& Lea 2002; Voelker et al. 2010). These less ventilated intermediate waters were most likely due to influx of fresher, colder and nutrient rich Subarctic Intermediate Water to the deep-water convection area of the Rockall Plateau (Álvarez et al. 2004), or to Antarctic Intermediate Water that penetrated farther northward like during the last deglaciation (Rickaby \& Elderfield 2005).

Finally, the observed decrease in the average $\delta^{13} \mathrm{C}$ at Site U1314 after $950 \mathrm{ka}$ (Fig. 5C) coincides with Kleiven et al. (2003) findings of a decrease in the glacial $\delta^{13} \mathrm{C}$ gradient between intermediate and deep sites after that age, suggesting stronger suppression of thermohaline circulation at all depths after MIS 25 that typify Late Pleistocene Terminations (Raymo 1997).

\section{Implications of the regional AF dynamic}

Thermal gradients between the east and west subpolar North Atlantic can be observed by comparing the differences in carbonate content of the sediments from Sites 984, 983, 980, 982 and U1314 (Table 1). In general, we observe synchronous fluctuations of carbonate sedimentation with higher carbonate values east of $20^{\circ} \mathrm{W}$ meridian, although differences were more pronounced before MIS 25. A comparison of carbonate records between the two farthest sites (984 and 980; $900 \mathrm{~km}$ away) shows differences $>60 \%$ (Fig. 7A). As high carbonate productivity fluctuations in this region were probably caused by variations in the extension of warm Atlantic water inflow (Baumann \& Huber 1999), we argue that spatial and temporal differences are related to the configuration of the AF. A dominant north-easterly position of the AF towards the Faeroe Islands, with relatively small AF swings until MIS 26, led to dominant arctic conditions with limited carbonate bioproductivity northwest of the AF, explaining the lower values at sites 984, 983 and U1314 (Fig. 8A). This situation is true for 
these locations today, where the inflow of warm and saline Atlantic water is compressed to the east, between Iceland and the Faeroe Islands and through the Faeroe-Shetland Channel as it flows northward into the GIN Seas (Orvik \& Niiler 2002), resulting in a strong west-east temperature gradient. These results also show that well ventilated intermediate waters formed in the Rockall Plateau even during G-IG transitions (Fig. 8A).

The structure of circulation changed during MIS 25, 21 and 19, with broader AF swings allowing a greater northward intrusion of warm surface waters that reached cores located in a more western position (Site 984, 980 and U1314) (Fig. 8B). The existence of greater flow of Atlantic waters into the GIN Seas during interglacial stages 25, 21 and 19 would provide the necessary moisture for growing ice-sheets during the glacial inception phase (Ruddiman \& McIntyre 1981c; Raymo \& Nisancioglu 2003), and thus may explain the build-up of larger ice-sheets in the Northern Hemisphere during the MPT. However, the influx of less saline arctic waters and/or melting icebergs during Terminations within this interval deflected the NAC water northward flow toward winter convection areas of the Rockall Plateau, causing a reduction in the carbonate productivity in the area and ventilation of intermediate waters (Fig. 8B).

Although faunal records from sites 980 and 984 only spans from 990 and 890 (respectively) to $779 \mathrm{ka}$, the striking differences observed in the composition of the planktonic foraminifera assemblages between those sites and U1314 can help to establish the position of the AF. Strong difference in the lower values of T. quinqueloba at westward sites U1314 and 984 compared to the eastward 980 reflect the almost steady position of the AF close to site 980 and far from the other two sites. After MIS 25, we observed lower percentages of $T$. quinqueloba at site 980 and higher percentages at U1314 and 984 (Fig. 7B;C). This may reflect a greater northwest retreat of the AF. For $N$. pachyderma sin., the most striking feature is the early decrease at site U1314 and 984 relative to site 980 during glacial inceptions of MIS 27, 25, 23 and 21. The gradual cooling at Site 980 indicated by this species, defined by 
Wright et al. (2002) as 'lagging warmth', may reflect a NAC compressed to the east, thus causing higher temperatures in the eastern areas while cooler waters bathed the western sites. This faunal evidence agrees with the regional differences in the $\mathrm{CaCO}_{3}$ content stated above, and highlights the strong longitudinal thermal gradient in the subpolar North Atlantic.

\section{Conclusions}

The planktonic foraminiferal assemblage record combined with $\mathrm{CaCO}_{3}$ content and $N$. pachyderma sin. $\delta^{13} \mathrm{C}$ data from IODP Site U1314 helps to define the surface and intermediate oceanographic changes during the Mid-Pleistocene Transition (MPT) (1069-779 ka). Higher percentages of $N$. pachyderma sin. indicate glacial conditions with a southeastward expansion of the $\mathrm{AF}$ and penetration of cold arctic waters. In contrast, high percentages of N. pachyderma dex., T. quinqueloba, G. bulloides, and G. inflata indicate interglacial conditions in the subpolar North Atlantic. Fluctuations in the contribution of polar (N. pachyderma $\sin$.$) vs. temperate (N. pachyderma dex. +$ G. inflata) fauna show a marked change since MIS 25, interpreted as due to a change in G-I periodicity from 40-ka to 100 -ka that characterizes the MPT (Berger \& Jansen 1994).

The higher PF AR during glacial inceptions, and lack of correlation of this record with the $\mathrm{CaCO}_{3} \%$, seems to indicate that planktonic foraminifera played a secondary role as calcium carbonate producers, with coccolithophores being dominant during interglacial stages, and $N$. pachyderma sin. colder periods.

Two different morphotypes of $N$. pachyderma sin. were recognized based on the degree of encrustration and shell structure. Lower SST and development of a strong pycnocline at the time of severe glacials MIS 22 and 20 at Site U1314 may have controlled the distribution of the encrusted morphotype, while the non-encrusted morphotype dominated phases with subsurface penetration of Atlantic waters. Synchronicity of encrusted morphotype 
of N. pachyderma sin. events in the subpolar North Atlantic (this study) and in the North Pacific (Kucera \& Kennett 2002) may suggest that this morphotype responded to strong environmental changes through time, thus making this analysis valuable for palaeoenvironmental interpretation. Shannon diversity index oscillations define surface circulation pattern in the North Atlantic; high diversity was related increased advection of the warm Atlantic current, while low diversity was typical of colder.

N. pachyderma sin. $\delta^{13} \mathrm{C}$ signature reflects conditions at the upper-part of the intermediate water layer. Minima in the N. pachyderma $\sin . \delta^{13} \mathrm{C}$ record during Terminations 24/23, 22/21 and 20/19, coinciding with low benthic $\delta^{13} \mathrm{C}$ values and high IRD input at Site 982, suggest cessation of intermediate water production (GNAIW) in the Rockall Plateau, and/or penetration of AAIW into the subpolar North Atlantic (Venz et al. 1999). Based on the planktonic $\delta^{13} \mathrm{C}$ values, the resumption of strong and ventilated intermediate North Atlantic was delayed until well into the subsequent interglacial, but was active during most of glacial stages because deep convection shifted south of the AF, around the Rockall Plateau.

We observe a strong longitudinal thermal (E-W) gradient in this part of the North Atlantic defined by the position of the AF. From MIS 31 to MIS 25, the AF was steady, located south of sites U1314 and 984, limiting heat flux westward, while eastward sites 980 and 982 were influenced by a more intense NAC flow, and allowed a northward transport of heat during glacial inceptions. As the result of the steep east-west surface SST gradient, $\mathrm{CaCO}_{3}$ productivity was lower north-west of the AF during this interval (sites 984, 983 and U1314). During MIS 22, the most extreme surface cold conditions are observed, likely with perennial sea-ice, a consequence of the southward migration of the PF. During MIS 21 and 19, greater retreat of AF allowed a regional warming that increased carbonate bioproductivity at the Site U1314 area.

\section{Acknowledgements}


This work was funded by Ministerio de Ciencia e Innovación Project GRACCIE (CONSOLIDER-INGENIO CSD 2007-00067) and CGL2008-05560/BTE as well as Junta de Castilla y Leon Grupo GR34, by a MEC FPI Grant to Iván Hernández-Almeida (BES-200612787), and by a grant from the US National Science Foundation (to G.M. Filippelli). We are grateful to Karl-Heinz Bauman for providing carbonate and fauna records from ODP Site 982. The manuscript benefited from the comments of Maryline Vautravers, Jon Eiriksson and other anonymous reviewer. This research used samples from IODP Expedition 306.

\section{References}

Alley, R. B. \& MacAyeal, D. R. 1994: Ice-rafted Debris Associated with Binge/Purge Oscillations of the Laurentide Ice Sheet. Paleoceanography 9, 503-511.

Alonso-Garcia, M., Sierro, F. J., Kucera, M., Flores, J. A., Cacho, I. \& Andersen, N. 2011: Ocean circulation, ice sheet growth and interhemispheric coupling of millennial climate variability during the mid-Pleistocene (ca 800-400 ka). Quaternary Science Reviews 30, 3234-3247.

Álvarez, M., Pérez, F. F., Bryden, H. \& Ríos, A. F. 2004: Physical and biogeochemical transports structure in the North Atlantic subpolar gyre. Journal of Geophysical Research 109, C03027. doi: 10.1029/2003jc002015

Andersson, C., Pausata, F. S. R., Jansen, E., Risebrobakken, B. \& Telford, R. J. 2009: Holocene trends in the foraminifer record from the Norwegian Sea and the North Atlantic Ocean. Climate of the Past Discussion 5, 2081-2113.

Baldauf, J. G. 1986: Diatom biostratigraphic and palaeoceanographic interpretations for the middle to high latitude North Atlantic Ocean. Geological Society, London, Special Publications 21, 243-252.

Balestra, B., Ziveri, P., Baumann, K.-H., Troelstra, S. \& Monechi, S. 2010: Surface water dynamics in the Reykjanes Ridge area during the Holocene as revealed by coccolith assemblages. Marine Micropaleontology 76, 1-10.

Balsam, W. L. \& Flessa, K. W. 1978: Patterns of planktonic foraminiferal abundance and diversity in surface sediments of the western North Atlantic. Marine Micropaleontology 3, 279-294.

Bauch, H. A. 1994: Significance of variability in Turborotalita quinqueloba (Natland) test size and abundance for paleoceanographic interpretations in the Norwegian-Greenland Sea. Marine Geology 121, 129-141.

Bauch, H. A. \& Kandiano, E. S. 2007: Evidence for early warming and cooling in North Atlantic surface waters during the last interglacial. Paleoceanography 22, PA1201. doi: $10.1029 / 2005 \mathrm{pa} 001252$

Baumann, K.-H. \& Huber, R. 1999: Sea-surface gradients between the North Atlantic and the Norwegian Sea during the last 3.1 m.y.: comparison of Sites 982 and 985. In Raymo, M. E., Jansen, E., Blum, P. \& Herbert, T. D. (eds.): Proceedings of the Ocean Drilling Program, Scientific Results 162, 179-190 pp. Ocean Drilling Program, College Station, TX. 
Bé, A. H. W. 1977: An ecological, zoogeographic and taxonomic review of recent planktonic foraminifera. In Ramsay, A. T. S. (ed.): Oceanic Micropaleontology, 1 1-100 pp. Academic Press, London.

Bé, A. W. H. 1960: Some observations on Arctic planktonic foraminifera. Contributions from the Cushman Foundation for Foraminiferal Research 11, 64-68.

Bé, A. W. H. \& Tolderlund, D. S. 1971: Distribution and ecology of living planktonic foraminifera in surface waters of the Atlantic and Indian Oceans. In Funnel, B. M. \& Riedel, W. R. (eds.): Micropaleontology of the Oceans, 105-149 pp. Cambridge University Press, Cambridge.

Bergami, C., Capotondi, L., Langone, L., Giglio, F. \& Ravaioli, M. 2009: Distribution of living planktonic foraminifera in the Ross Sea and the Pacific sector of the Southern Ocean (Antarctica). Marine Micropaleontology 73, 37-48.

Berger, W. H. \& Jansen, E. 1994: Mid-Pleistocene climate shift: the Nansen connection. In Johannessen, T., Muench, R. D. \& Overland, J. E. (eds.): The Polar Oceans and Their Role in Shaping the Global Environment: The Nansen Centennial Volume, 295-311 pp. AGU, Geophysical Monographs Washington D.C.

Bianchi, G. G. \& McCave, I. N. 2000: Hydrography and sedimentation under the deep western boundary current on Björn and Gardar Drifts, Iceland Basin. Marine Geology $165,137-169$.

Biscaye, P. E., Kolla, V. \& Turekian, K. K. 1976: Distribution of Calcium Carbonate in Surface Sediments of the Atlantic Ocean. Journal of Geophsycal Research 81, 25952603.

Broecker, W. 1991: The Great Ocean Conveyor. Oceanography 4, 79-89.

Broecker, W., Bond, G., Klas, M., Clark, E. \& McManus, J. 1992: Origin of the northern Atlantic's Heinrich events. Climate Dynamics 6, 265-273.

Broecker, W. S. 1994: Massive iceberg discharges as triggers for global climate change. Nature 372, 421-424.

Broecker, W. S. \& Peng, T. H. 1982: Tracers in the sea. 690 pp. Eldigio Press, Palisades, N.Y.

Broecker, W. S. \& Takahashi, T. 1978: The relationship between lysocline depth and in situ carbonate ion concentration. Deep-Sea Research 25, 65-95.

Carstens, J. \& Wefer, G. 1992: Recent distribution of planktonic foraminifera in the Nansen Basin, Arctic Ocean. Deep Sea Research Part A. Oceanographic Research Papers 39, S507-S524.

Channell, J. E. T., Kanamatsu, T., Sato, T., Stein, R., Alvarez Zarikian, C. A., Malone, M. J. \& Expedition 303/306 Scientists 2006: Expedition 306 summary. In Channell, J. E. T., Kanamatsu, T., Sato, T., Stein, R., Alvarez Zarikian, C. A., Malone, M. J. \& Expedition 303/306 Scientists (eds.): Proceedings Integrated Ocean Drilling Program, Expedition 303/306, 1-29 pp. Integrated Ocean Drilling Program, College Station, TX.

Chapman, M. R. 2010: Seasonal production patterns of planktonic foraminifera in the NE Atlantic Ocean: Implications for paleotemperature and hydrographic reconstructions. Paleoceanography 25, PA1101. doi: 10.1029/2008pa001708

Cifelli, R. 1973: Observations on Globigerina pachyderma (Ehrenberg) and Globigerina incompta Cifelli from the North Atlantic. The Journal of Foraminiferal Research 3, 157-166.

Clark, P. U., Archer, D., Pollard, D., Blum, J. D., Rial, J. A., Brovkin, V., Mix, A. C., Pisias, N. G. \& Roy, M. 2006: The middle Pleistocene transition: characteristics, mechanisms, and implications for long-term changes in atmospheric pCO2. Quaternary Science Reviews 25, 3150-3184.

Coplen, T. B. 1996: More uncertainty than necessary. Paleoceanography 11, 369-370. 
Dickson, R. R. \& Brown, J. 1994: The production of North Atlantic Deep Water: Sources, rates, and pathways. Journal of Geophsycal Research 99, 12319-12341.

Dowling, L. M. \& McCave, I. N. 1993: Sedimentation on the Feni Drift and late Glacial bottom water production in the northern Rockall Trough. Sedimentary Geology 82, 7987.

Eynaud, F., Cronin, T. M., Smith, S. A., Zaragosi, S., Mavel, J., Mary, Y., Mas, V. \& Pujol, C. 2009: Morphological variability of the planktonic foraminifer Neogloboquadrina pachyderma from ACEX cores: Implications for Late Pleistocene circulation in the Arctic Ocean. Micropaleontology 55, 101-106.

Ferretti, P., Crowhurst, S. J., Hall, M. A. \& Cacho, I. 2010: North Atlantic millennial-scale climate variability 910 to $790 \mathrm{ka}$ and the role of the equatorial insolation forcing. Earth and Planetary Science Letters 293, 28-41.

Fraile, I., Schulz, M., Mulitza, S. \& Kucera, M. 2008: Predicting the global distribution of planktonic foraminifera using a dynamic ecosystem model. Biogeosciences 5, 891911.

Fronval, T., Jansen, E., Haflidason, H. \& Sejrup, J. P. 1998: Variability in surface and deep water conditions in the Nordic seas during the last interglacial period. Quaternary Science Reviews 17, 963-985.

Hald, M., Andersson, C., Ebbesen, H., Jansen, E., Klitgaard-Kristensen, D., Risebrobakken, B., Salomonsen, G. R., Sarnthein, M., Sejrup, H. P. \& Telford, R. J. 2007: Variations in temperature and extent of Atlantic Water in the northern North Atlantic during the Holocene. Quaternary Science Reviews 26, 3423-3440.

Head, M. J. \& Gibbard, P. L. 2005: Early-Middle Pleistocene transitions: an overview and recommendation for the defining boundary. Geological Society, London, Special Publications 247, 1-18.

Hebbeln, D., Dokken, T., Andersen, E. S., Hald, M. \& Elverhoi, A. 1994: Moisture supply for northern ice-sheet growth during the Last Glacial Maximum. Nature 370, 357-360.

Hemleben, C., Spindler, M. \& Anderson, O. R. 1989: Modern planktic foraminifera. 363 pp. Springer Verlag, New York.

Henrich, R. 1989: Glacial/Interglacial cycles in the Norwegian Sea: sedimentology, paleoceanographyu and evolution of Late Pliocene to Quaternary Northern Hemisphere climate. In Eldholm, O., Thiede, J. \& Taylor, E. (eds.): Proceedings of the Ocean Drilling Program, Scientific Results 104, 189-232 pp. Ocean Drilling Program, College Station, TX.

Henrich, R. 1998: Dynamics of Atlantic water advection to the Norwegian-Greenland Sea - a time-slice record of carbonate distribution in the last $300 \mathrm{ky}$. Marine Geology 145, 95131.

Henrich, R., Baumann, K.-H., Huber, R. \& Meggers, H. 2002: Carbonate preservation records of the past $3 \mathrm{Myr}$ in the Norwegian-Greenland Sea and the northern North Atlantic: implications for the history of NADW production. Marine Geology 184, 17-39.

Henrich, R. \& Baumann, K. H. 1994: Evolution of the Norwegian Current and the Scandinavian Ice Sheets during the past 2.6 m.y.: evidence from ODP Leg 104 biogenic carbonate and terrigenous records. Palaeogeography, Palaeoclimatology, Palaeoecology 108, 75-94.

Hernández-Almeida, I., Sierro, F. J., Cacho, I. \& Flores, J. A. 2012: Impact of suborbital climate changes in the North Atlantic on ice-sheets dynamics at the Mid-Pleistocene Transition. Paleoceanography, in press. doi: 10.1029/2011PA002209

Hillaire-Marcel, C. \& Bilodeau, G. 2000: Instabilities in the Labrador Sea water mass structure during the last climatic cycle. Canadian Journal of Earth Sciences 37, 795809. 
Hillaire-Marcel, C., de Vernal, A., Candon, L., Bilodeau, G. \& Stoner, J. 2001a: Changes of potential density gradients in the northwestern North Atlantic during the last climatic cycle based on a multiproxy approach. In Seidov, D., Maslin, M. \& Haupt, B. J. (eds.): The Oceans and Rapid Climate Change: Past, Present, and Future, 126 83-100 pp. American Geophysical Union, Washington D.C.

Hillaire-Marcel, C., de Vernal, A. \& McKay, J. 2011: Foraminifer isotope study of the Pleistocene Labrador Sea, northwest North Atlantic (IODP Sites 1302/03 and 1305), with emphasis on paleoceanographical differences between its "inner" and "outer" basins. Marine Geology 279, 188-198.

Hillaire-Marcel, C., de Vernal, A., Polyak, L. \& Darby, D. 2004: Size-dependent isotopic composition of planktic foraminifers from Chukchi Sea vs. NW Atlantic sedimentsimplications for the Holocene paleoceanography of the western Arctic. Quaternary Science Reviews 23, 245-260.

Hodell, D. A., Channell, J. E. T., Curtis, J. H., Romero, O. E. \& Röhl, U. 2008: Onset of "Hudson Strait" Heinrich events in the eastern North Atlantic at the end of the middle Pleistocene transition ( $640 \quad \mathrm{ka})$ ? Paleoceanography 23, PA4218. doi:10.1029/2008PA001591

Huddlestun, P. F. 1984: Planktonic Foraminiferal Biostratigraphy, Deep Sea Drilling Project Leg 81. In Roberts, D. G., Schnitker, D., Backman, J., Baldauf, J. G., Desprairies, A., Homrighausen, R., Huddlestun, P., Kaltenback, A. J., Krumsiek, K. A. O., Morton, A. C., Murray, J. W., Westberg-Smith, J. \& Zimmerman, H. B. (eds.): Initial Reports of the Deep Sea Drilling Project, Leg 81, 429-438 pp. U.S. Government Printing Office, Washington D.C.

Huizhong, W. \& McCave, I. N. 1990: Distinguishing climatic and current effects in midPleistocene sediments of Hatton and Gardar Drifts, NE Atlantic. Journal of the Geological Society 147, 373-383.

Ikeda, A., Okada, H. \& Koizumi, I. 2000: Data report: late Miocene to Pleistocene diatoms from the Blake Ridge, Site 997. In Paull, C. K., Matsumoto, R., Wallace, P. J. \& Dillon, W. P. (eds.): Proceedings of the Ocean Drilling Program, Scientific Results 164, 164 365-376 pp. Ocean Drilling Program, College Station, TX.

IODP-USIO 2007: Janus Web Database. http://iodp.tamu.edu/janusweb/general/dbtable.cgi.

Jenkins, D. G. 1993: The evolution of the Cenozoic southern high- and mid-latitude planktonic foraminiferal faunas. In Kennett, J. P. \& Warnke, D. A. (eds.): The Antarctic Paleoenvironment: a Perspective on Global Change, 60 175-194 pp. American Geophysics Union, Washington, D.C.

Johannessen, T., Jansen, E., Flatoy, A. \& Ravelo, A. C. 1994: The relationship between surface water masses, oceanographic fronts and paleoclimatic proxies in surface sediments of the Greenland, Iceland, Norwegian seas. In Zahn, R., Pedersen, T. F., Kaminski, M. A. \& Labeyrie, L. (eds.): Carbon cycling in the glacial ocean: constraints on the oceans's role in global change., 61-85 pp. Springer-Verlag, Berlin.

Kandiano, E. S., Bauch, H. A. \& Müller, A. 2004: Sea surface temperature variability in the North Atlantic during the last two glacial-interglacial cycles: comparison of faunal, oxygen isotopic, and $\mathrm{Mg} / \mathrm{Ca}$-derived records. Palaeogeography, Palaeoclimatology, Palaeoecology 204, 145-164.

Kipp, N. G. 1976: New transfer function for estimating past sea-surface conditions from seabed distribution of planktonic foraminiferal assemblages in the North Atlantic. In Cline, R. M. \& Hays, J. D. (eds.): Investigations of Late Quaternary Palaeoceanography and Palaeoclimatology, 3-42 pp. Geolgical Society of America, Boulder, CO. 
Kleiven, H. F., Hall, I. R., McCave, I. N., Knorr, G. \& Jansen, E. 2011: Coupled deep-water flow and climate variability in the middle Pleistocene North Atlantic. Geology 39, 343-346.

Kleiven, H. F., Jansen, E., Curry, W. B., Hodell, D. A. \& Venz, K. 2003: Atlantic Ocean thermohaline circulation changes on orbital to suborbital timescales during the midPleistocene. Paleoceanography 18, 1008. doi: 10.1029/2001 pa000629

Koç, N. \& Flower, B., P. 1998: High-resolution Pleistocene diatom biostratigraphy and paleoceanography of site 919 from the Irminger Basin. In Saunders, A. D., Larsen, H. C. \& Wise, S. W. (eds.): Proceedings of the Ocean Drilling Program, Scientific Results 152, 202-219 pp. Ocean Drilling Program, College Station, TX.

Koç, N., Hodell, D., A., Kleiven, H. \& Labeyrie, L. 1999: High-resolution Pleistocene diatom biostratigraphy of site 983 and correlations with isotope stratigraphy. In Raymo, M. E., Jansen, E., Blum, P. \& Herbert, T. D. (eds.): Proceedings of the Ocean Drilling Program, Scientific Results 162, 162 51-62 pp. Ocean Drilling Program, College Station, TX.

Kohfeld, K. E., Fairbanks, R. G., Smith, S. L. \& Walsh, I. D. 1996: Neogloboquadrina pachyderma (sinistral coiling) as Paleoceanographic Tracers in Polar Oceans: Evidence from Northeast Water Polynya Plankton Tows, Sediment Traps, and Surface Sediments. Paleoceanography 11, 679-699.

Krauss, W. 1986: The North Atlantic Current. Journal of Geophysical Research 91, 50615074.

Kroopnick, P. M. 1985: The distribution of ${ }^{13} \mathrm{C}$ of $\Sigma \mathrm{CO}_{2}$ in the world oceans. Deep Sea Research Part A. Oceanographic Research Papers 32, 57-84.

Kucera, M. \& Kennett, J. P. 2002: Causes and consequences of a middle Pleistocene origin of the modern planktonic foraminifer Neogloboquadrina pachyderma sinistral. Geology 30, 539-542.

Labeyrie, L. D. \& Duplessy, J. C. 1985: Changes in the oceanic $\delta^{13} \mathrm{C} / \delta^{12} \mathrm{C}$ ratio during the last 140000 years: High-latitude surface water records. Palaeogeography, Palaeoclimatology, Palaeoecology 50, 217-240.

Lisiecki, L. E. \& Raymo, M. E. 2005: A Pliocene-Pleistocene stack of 57 globally distributed benthic $\delta^{18} \mathrm{O}$ records. Paleoceanography 20, PA1003. doi: 10.1029/2004PA001071

Marino, M., Maiorano, P. \& Flower, B. P. 2011: Calcareous nannofossil changes during the Mid-Pleistocene Revolution: Paleoecologic and paleoceanographic evidence from North Atlantic Site 980/981. Palaeogeography, Palaeoclimatology, Palaeoecology 306, 58-69.

Marino, M., Maiorano, P. \& Lirer, F. 2008: Changes in calcareous nannofossil assemblages during the Mid-Pleistocene Revolution. Marine Micropaleontology 69, 70-90.

McCave, I. N., Manighetti, B. \& Robinson, S. G. 1995: Sortable silt and fine sediment size/composition slicing: parameters for palaeocurrent speed and palaeoceanography. Paleoceanography 10, 593-610.

McClymont, E. L., Rosell-Melé, A., Haug, G. H. \& Lloyd, J. M. 2008: Expansion of subarctic water masses in the North Atlantic and Pacific oceans and implications for midPleistocene ice sheet growth. Paleoceanography 23, PA4214. doi: $10.1029 / 2008 \mathrm{pa} 001622$

McIntyre, A., Ruddiman, W. F. \& Jantzen, R. 1972: Southward penetrations of the North Atlantic polar front: faunal and floral evidence of large-scale surface water mass movements over the last 225,000 years. Deep Sea Research and Oceanographic Abstracts 19, 61-77.

Miao, Q., Thunell, R. C. \& Anderson, D. M. 1994: Glacial-Holocene Carbonate Dissolution and Sea Surface Temperatures in the South China and Sulu Seas. Paleoceanography 9, 269-290. 
Moller, T., Schulz, H. \& Kucera, M. 2011: The effect of sea surface properties on shell morphology and size of the planktonic foraminifer Neogloboquadrina pachyderma in the North Atlantic. Palaeogeography, Palaeoclimatology, Palaeoecology, in press.

Mudelsee, M. \& Schulz, M. 1997: The Mid-Pleistocene climate transition: onset of $100 \mathrm{ka}$ cycle lags ice volume build-up by $280 \mathrm{ka}$. Earth and Planetary Science Letters 151, 117-123.

Olson, H. C. \& Smart, C. W. 2004: Pleistocene climatic history reflected in planktonic foraminifera from ODP Site 1073 (Leg 174A), New Jersey margin, NW Atlantic Ocean. Marine Micropaleontology 51, 213-238.

Oppo, D. W. \& Lehman, S. J. 1993: Mid-Depth Circulation of the Subpolar North Atlantic During the Last Glacial Maximum. Science 259, 1148-1152.

Ortiz, J., Mix, A., Harris, S. \& O'Connell, S. 1999: Diffuse Spectral Reflectance as a Proxy for Percent Carbonate Content in North Atlantic Sediments. Paleoceanography 14, 171-186.

Orvik, K. A. \& Niiler, P. 2002: Major pathways of Atlantic water in the northern North Atlantic and Nordic Seas toward Arctic. Geophysical Research Letters 29, 1896. doi: $10.1029 / 2002 \mathrm{gl015002}$

Paillard, D. L. \& Yiou, P. 1996: Macintosh program performs time-series analysis. Eos Transactions, American Geophysical Union 77, 379. doi:10.1029/96EO00259

Pflaumann, U., Sarnthein, M., Chapman, M., d'Abreu, L., Funnell, B., Huels, M., Kiefer, T., Maslin, M., Schulz, H., Swallow, J., van Kreveld, S., Vautravers, M., Vogelsang, E. \& Weinelt, M. 2003: Glacial North Atlantic: Sea-surface conditions reconstructed by GLAMAP 2000. Paleoceanography 18, 1065-1093.

Pielou, E. C. 1975: Ecological diversity. 165 pp. Wiley, New York.

Poore, R. Z. \& Berggren, W. A. 1975: Late Cenozoic planktonic foraminiferal biostratigraphy and paleoclimatology of Hatton-Rockall Basin; DSDP Site 116. Journal of Foraminiferal Research 5, 270-293.

Rasmussen, T. L., Thomsen, E., Troelstra, S. R., Kuijpers, A. \& Prins, M. A. 2003b: Millennial-scale glacial variability versus Holocene stability: changes in planktic and benthic foraminifera faunas and ocean circulation in the North Atlantic during the last 60,000 years. Marine Micropaleontology 47, 143-176.

Raymo, M. E. 1997: The timing of major climate Terminations. Paleoceanography 12, 577585.

Raymo, M. E. \& Nisancioglu, K. 2003: The 41 kyr world: Milankovitch's other unsolved mystery. Paleoceanography 18, 1011-1017.

Raymo, M. E., Oppo, D. W. \& Curry, W. 1997: The Mid-Pleistocene Climate Transition: A Deep Sea Carbon Isotopic Perspective. Paleoceanography 12, 546-559.

Raymo, M. E., Oppo, D. W., Flower, B. P., Hodell, D. A., McManus, J. F., Venz, K. A., Kleiven, K. F. \& McIntyre, K. 2004: Stability of North Atlantic water masses in face of pronounced climate variability during the Pleistocene. Paleoceanography 19, PA2008. doi: 10.1029/2003pa000921

Reid, P. C., Johns, D. G., Edwards, M., Starr, M., Poulin, M. \& Snoeijs, P. 2007: A biological consequence of reducing Arctic ice cover: arrival of the Pacific diatom Neodenticula seminae in the North Atlantic for the first time in 800000 years. Global Change Biology 13, 1910-1921.

Reynaud, T. H., Weaver, A. J. \& Greatbatch, R. J. 1995: Summer mean circulation of the northwestern Atlantic Ocean. Journal of Geophsycal Research 100, 779-816.

Rickaby, R. E. M. \& Elderfield, H. 2005: Evidence from the high-latitude North Atlantic for variations in Antarctic Intermediate water flow during the last deglaciation. Geochemostry Geophysics Geosystem 6, Q05001. doi: 10.1029/2004gc000858 
Ruddiman, W. F. 1969: Recent Planktonic Foraminifera: Dominance and Diversity in North Atlantic Surface Sediments. Science 164, 1164-1167.

Ruddiman, W. F. 1977: Late Quaternary deposition of ice-rafted sand in the subpolar North Atlantic (lat $40^{\circ}$ to $65^{\circ} \mathrm{N}$ ). Geological Society of America Bulletin 88, 1813-1827.

Ruddiman, W. F. \& McIntyre, A. 1981c: Oceanic Mechanisms for Amplification of the 23,000-Year Ice-Volume Cycle. Science 212, 617-627.

Ruddiman, W. F., Raymo, M. E., Martinson, D. G., Clement, B. M. \& Backman, J. 1989: Pleistocene evolution: Northern hemisphere ice sheets and North Atlantic Ocean. Paleoceanography 4, 353-412.

Rutherford, S., D'Hondt, S. \& Prell, W. 1999: Environmental controls on the geographic distribution of zooplankton diversity. Nature 400, 749-753.

Sautter, L. R. \& Thunell, R. C. 1989: Seasonal succession of planktonic foraminifera; results from a four-year time-series sediment trap experiment in the Northeast Pacific. Journal of Foraminiferal Research 19, 253-267.

Schiebel, R. \& Hemleben, C. 2000: Interannual variability of planktic foraminiferal populations and test flux in the eastern North Atlantic Ocean (JGOFS). Deep Sea Research Part II: Topical Studies in Oceanography 47, 1809-1852.

Schiebel, R., Waniek, J., Bork, M. \& Hemleben, C. 2001: Planktic foraminiferal production stimulated by chlorophyll redistribution and entrainment of nutrients. Deep-Sea Research I 48, 721- 740.

Schlitzer, R. 2008: Ocean Data View, http://odv.awi.de.

Schmitz, W. J., Jr. \& McCartney, M. S. 1993: On the North Atlantic Circulation. Reviews of Geophysics 31, 29-49.

Shannon, C. E. \& Weaver, W. 1963: The mathematical theory of communication. 144 pp. University of Illinois Press.

Shimada, C., Sato, T., Toyoshima, S., Yamasaki, M. \& Tanimura, Y. 2008: Paleoecological significance of laminated diatomaceous oozes during the middle-to-late Pleistocene, North Atlantic Ocean (IODP Site U1304). Marine Micropaleontology 69, 139-150.

Simstich, J., Sarnthein, M. \& Erlenkeuser, H. 2003: Paired $\delta^{18} \mathrm{O}$ signals of Neogloboquadrina pachyderma (s) and Turborotalita quinqueloba show thermal stratification structure in Nordic Seas. Marine Micropaleontology 48, 107-125.

Spero, H. J. \& Lea, D. W. 2002: The Cause of Carbon Isotope Minimum Events on Glacial Terminations. Science 296, 522-525.

Spindler, M. \& Dieckmann, G. S. 1986: Distribution and abundance of the planktic foraminifer Neogloboquadrina pachyderma in sea ice of the Weddell Sea (Antarctica). Polar Biology 5, 185-191.

Srinivasan, M. S. \& Kennett, J. P. 1974: Secondary calcification of the planktonic foraminifer Neogloboquadrina pachyderma as a climatic index. Science 186, 630-632.

Stangeew, E. 2001: Distribution and isotopic composition of living planktonic foraminifera $N$. pachyderma (sinistral) and T. quinqueloba in the high latitude North Atlantic. 98 pp. Phd Thesis, Christian-Albrechts-Universität zu Kiel, Kiel, Germany.

Stehli, F. G. 1965: Paleontologic Technique for Defining Ancient Ocean Currents. Science $148,943-946$.

Swift, J. H. 1984: The circulation of the Denmark Strait and Iceland-Scotland overflow waters in the North Atlantic. Deep Sea Research Part A. Oceanographic Research Papers 31, 1339-1355.

Swift, J. H. \& Aagaard, K. 1981: Seasonal transitions and water mass formation in the Iceland and Greenland seas. Deep Sea Research Part A. Oceanographic Research Papers 28, 1107-1129.

Thunell, R. C. 1976: Optimum indices of calcium carbonate dissolution, in deep-sea sediments. Geology 4, 525-528. 
Tolderlund, D. S. \& Be, A. W. H. 1971: Seasonal distribution of planktonic foraminifera in the western North Atlantic. Micropaleontology 17, 297-329.

Tziperman, E. \& Gildor, H. 2003: On the mid-Pleistocene transition to 100-kyr glacial cycles and the asymmetry between glaciation and deglaciation times. Paleoceanography 18 , 1001. doi: 10.1029/2001pa000627

van Aken, H. M. 2000: The hydrography of the mid-latitude Northeast Atlantic Ocean: II: The intermediate water masses. Deep Sea Research Part I: Oceanographic Research Papers 47, 789-824.

Van Iperen, J. \& Helder, W. 1985: A method for the determination of organic carbon in calcareous marine sediments. Marine Geology 64, 179-187.

van Kreveld, S. A., Knappertsbusch, M., Ottens, J., Ganssen, G. M. \& van Hinte, J. E. 1996: Biogenic carbonate and ice-rafted debris (Heinrich layer) accumulation in deep-sea sediments from a Northeast Atlantic piston core. Marine Geology 131, 21-46.

Venz, K. A., Hodell, D. A., Stanton, C. \& Warnke, D. A. 1999: A 1.0 Myr Record of Glacial North Atlantic Intermediate Water Variability from ODP Site 982 in the Northeast Atlantic. Paleoceanography 14, 42-52.

de Vernal, A., Hillaire-Marcel, C. \& Darby, D. A. 2005: Variability of sea ice cover in the Chukchi Sea (western Arctic Ocean) during the Holocene. Paleoceanography 20, PA4018. doi: 10.1029/2005pa001157

de Vernal, A., Hillaire-Marcel, C., Peltier, W. R. \& Weaver, A. J. 2002: Structure of the upper water column in the northwest North Atlantic: Modern versus Last Glacial Maximum conditions. Paleoceanography 17, 1050. doi: 10.1029/2001 pa000665

Vilks, G. 1974: The distribution of planktonic foraminifera in the sediments and water of the northwest passage and northern Baffin Bay: a tool for paleoceanographic synthesis. Geological Survey of Canada 1, 109-121.

Voelker, A. H. L., Rodrigues, T., Billups, K., Oppo, D., McManus, J., Stein, R., Hefter, J. \& Grimalt, J. O. 2010: Variations in mid-latitude North Atlantic surface water properties during the mid-Brunhes (MIS 9-14) and their implications for the thermohaline circulation. Climate of the Past 6, 531-552.

Volkmann, R. \& Mensch, M. 2001: Stable isotope composition $\delta^{18} \mathrm{O}, \delta^{13} \mathrm{C}$ of living planktic foraminifers in the outer Laptev Sea and the Fram Strait. Marine Micropaleontology 42, 163-188.

Wright, A. K. \& Flower, B. P. 2002: Surface and deep ocean circulation in the subpolar North Atlantic during the mid-Pleistocene revolution. Paleoceanography 17, 1068. doi:10.1029/2002PA000782

Wu, G. \& Hillaire-Marcel, C. 1994: Oxygen isotope compositions of sinistral Neogloboquadrina pachyderma tests in surface sediments: North Atlantic Ocean. Geochimica et Cosmochimica Acta 58, 1303-1312. 


\section{FIGURE CAPTIONS}

Table 1. Site information.

Figure 1. Location of IODP Site U1314 (black star: $56^{\circ} 21^{\prime} \mathrm{N}, 27^{\circ} \mathrm{W} ; 2820 \mathrm{~m}$ water depth), and other North Atlantic sites (see Table 1). Modern surface (red), and deep circulation (blue) in the North Atlantic (Krauss 1986; Schmitz \& McCartney 1993). Map generated with Ocean Data View v.3.4.3. software (Schlitzer 2008). EGC = East Greenland Current; NC Norwegian Current; LC = Labrador Current); NAC $=$ North Atlantic Current; IC = Irminger Current; DSOW = Denmark Strait Overflow Water; ISOW = Iceland Scotland Overflow Water; LSW = Labrador Sea Water $($ LSW); NADW = North Atlantic Deep Water; LDW = Lower Deep Water.

Figure 2. Scanning electron microscopy images from Site U1314 specimens demonstrate the physical differences between nonencrusted morphotypes of $N$. pachyderma dex. (A, B); the nonencrusted morphotypes (C, D) and encrusted morphotypes (E-L) of $N$. pachyderma sin. Close examination of these same specimens shows differences on density of calcite crust. Nonencrusted morphotypes of $N$. pachyderma sin. and $N$. pachyderma dex. (M, N, respectively) show lower density than encrusted morphotypes of $N$. pachyderma $\sin .(\mathrm{O}, \mathrm{P})$, with a denser calcite crust around shell pores. Scale bars for A-L are $50 \mu \mathrm{m}$, and $20 \mu \mathrm{m}$ for M-P.

Figure 3. Site U1314 records from 1069 to $779 \mathrm{ka}$. A. Benthic $\delta^{18} \mathrm{O}$. B. Relative abundance of $N$. pachyderma sin. encrusted morphotype. C. Shannon diversity index $(H)$. Glacial Marine Isotope Stages (MIS) are shown with blue vertical bars. Suborbital-scale climate events described by Hernández-Almeida et al. (2012) are shown with red vertical bars.

Figure 4. Relative abundance of the planktonic foraminfera species at Site U1314. A. N. pachyderma sin.. B. N. pachyderma dex. C. G. inflata. D. G. bulloides. E. T. quinqueloba. F. G. glutinata. Glacial Marine Isotope Stages (MIS) are shown with blue vertical bars. Suborbital-scale climate events described by Hernández-Almeida et al. (2012) are shown with red vertical bars. 
Figure 5. Site U1314 records from 1069 to $779 \mathrm{ka}$. A. Benthic $\delta^{18} \mathrm{O}$ from C. wuellerstorfi. B. Relative abundance of $N$. pachyderma sin. (black) versus N. pachyderma dex. + G. inflata (dashed grey). C. Planktonic $\delta^{13} \mathrm{C}$ record from Site U1314 (black) vs. benthic $\delta^{13} \mathrm{C}$ from Site 982 (blue) (Venz et al. 1999). D. Site 982 IRD\% (Venz et al. 1999). E. Site U1314 IRD\%. For better comparison between both sites, U1314 N. pachyderma $\sin . \delta^{13} \mathrm{C}$ data was adjusted to a 'Cibicidoides' scale, by adding 0.9\% (Labeyrie \& Duplessy 1985). Benthic $\delta^{18} \mathrm{O}$ record from 982 was used to correlate the $\delta^{13} \mathrm{C}$ record from this site to the LR04 benthic $\delta^{18} \mathrm{O}$ stack. Glacial Marine Isotope Stages (MIS) are shown with blue vertical bars. Suborbital-scale climate events described by Hernández-Almeida et al. (2012) are shown with red vertical bars.

Figure 6. A. $\mathrm{CaCO}_{3} \%$ from Site U1314. B. PF AR. C. $N$. pachyderma sin. AR D. Subpolar species ( $N$. pachyderma dex., G. inflata, G. bulloides, G. glutinata and T. quinqueloba) AR (red) vs. $\mathrm{CaCO}_{3} \%$ from Site U1314 (grey). E. Fragmentation Index. F. B/B+P ratio. Glacial Marine Isotope Stages (MIS) are shown with blue vertical bars. Suborbital-scale climate events described by Hernández-Almeida et al. (2012) are shown with red vertical bars.

Figure 7. Comparison of fauna and $\mathrm{CaCO}_{3} \%$ record from Site U1314 with other North Atlantic sites. A. $\mathrm{CaCO}_{3} \%$ records from sites U1314 (black), 982 (blue), 980 (dashed red), 983 (orange) and 984 (green) (Baumann \& Huber 1999; Ortiz et al. 1999). Relative contributions of (B) T. quinqueloba and (C) N. pachyderma sin. from sites U1314 (black), 980 (dashed red) and 984 (green) (Wright \& Flower 2002). Glacial Marine Isotope Stages (MIS) are shown with blue vertical bars. Suborbital-scale climate events described by Hernández-Almeida et al. (2012) are shown with red vertical bars.

Figure 8. The subpolar North Atlantic inferring the average glacial (black) and interglacial (grey) Arctic Front positions and surface circulation (A) between MIS 31-26; and (B) between MIS 25-19. Blue ellipse in (A) indicates intermediate water formation area (Venz et al. 1999) and arrows of the same colour designate intermediate waters. Grey ellipse in (B) indicates cessation of GNAIW production during Terminations noted in the figure. 


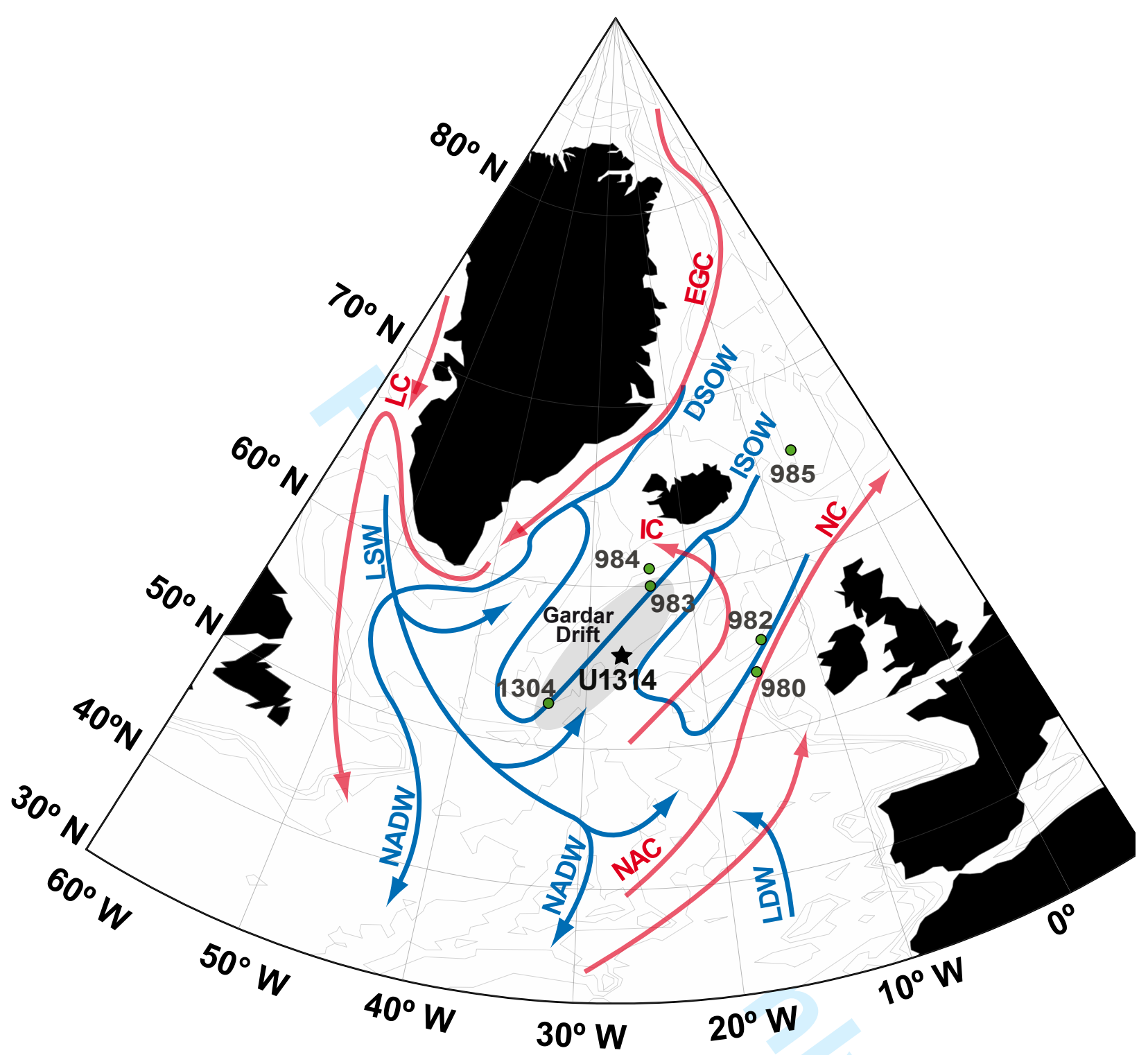



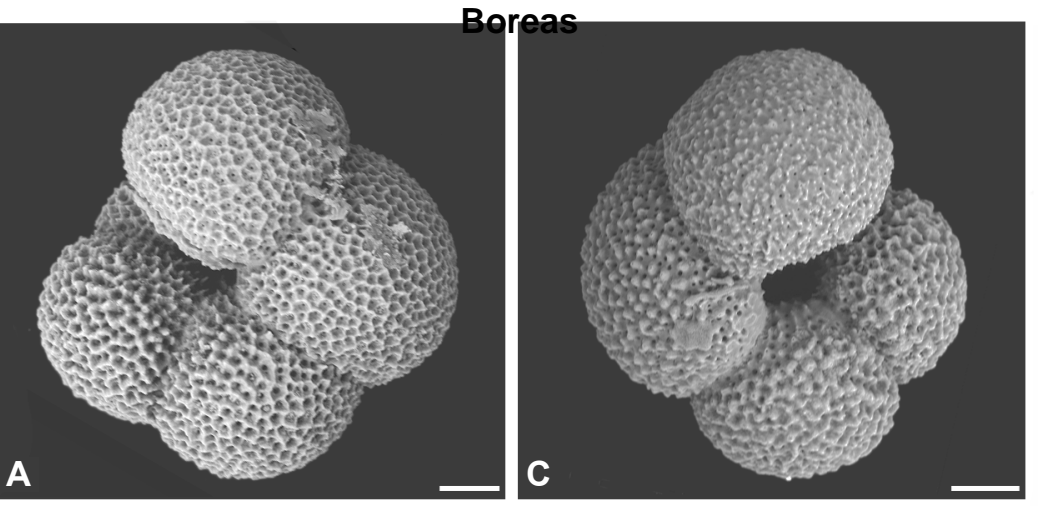

E
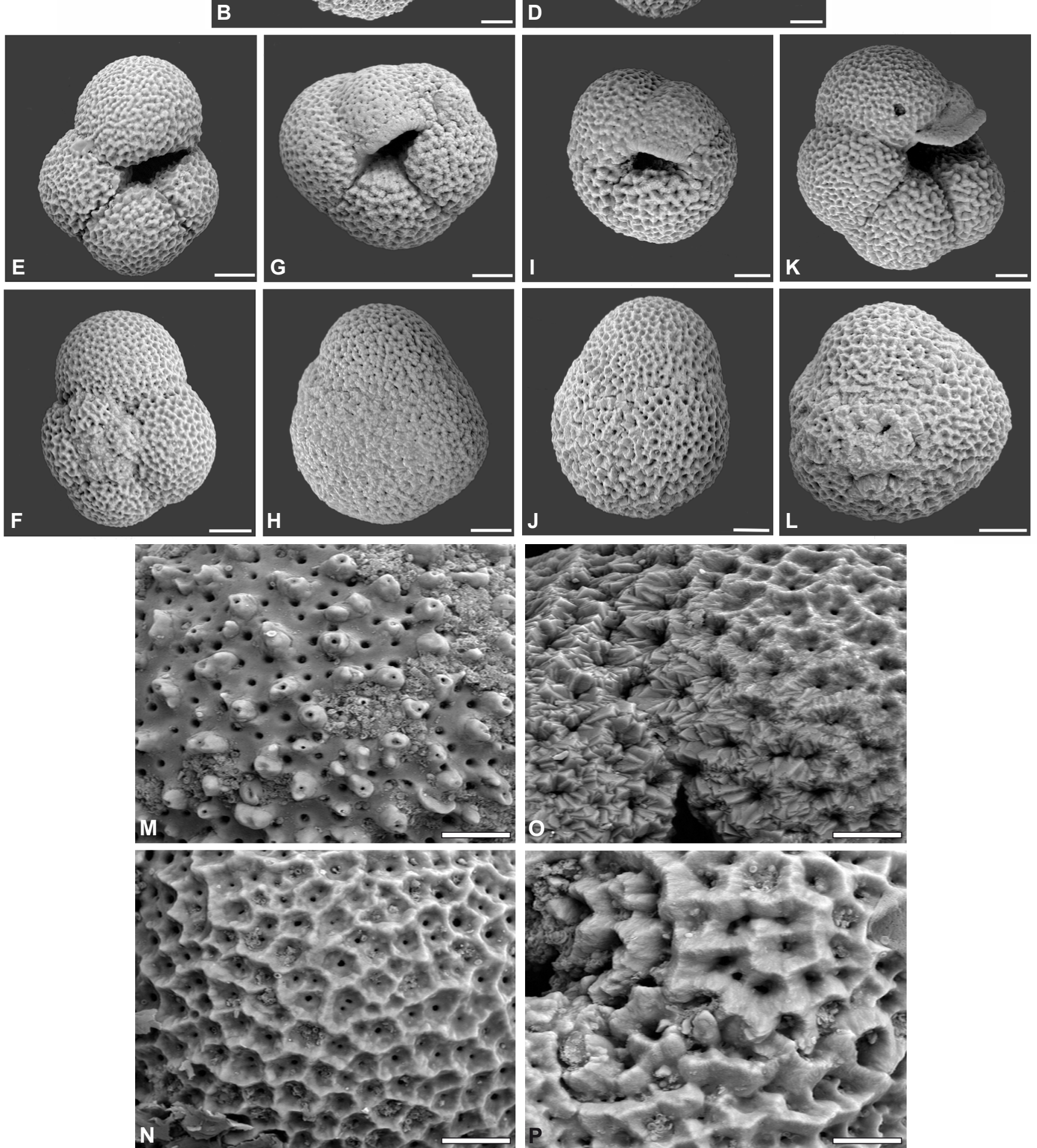

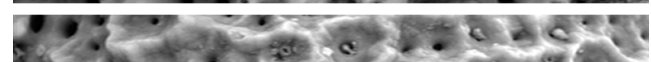

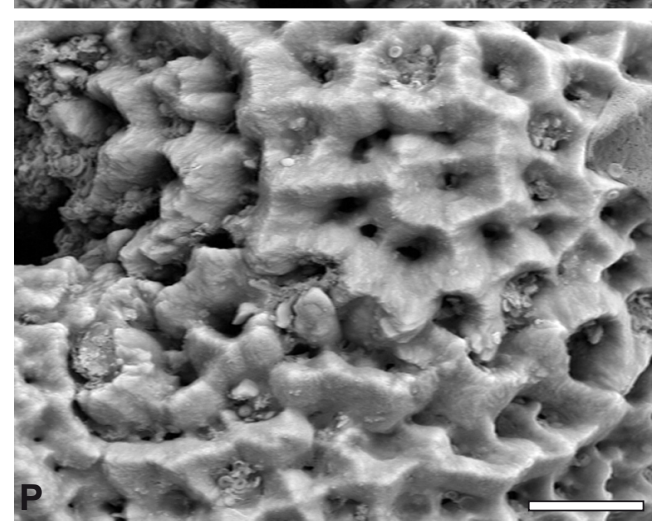




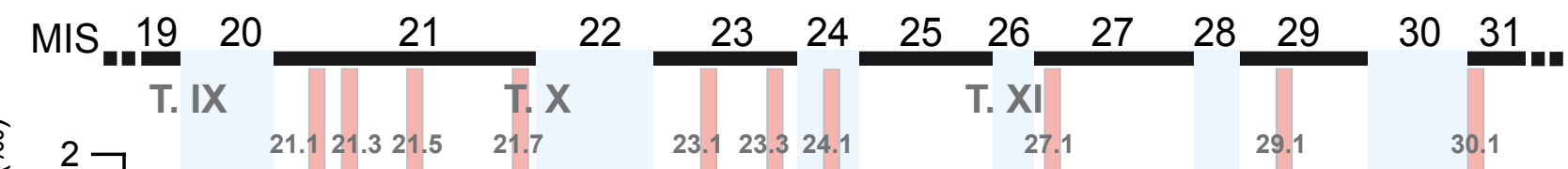

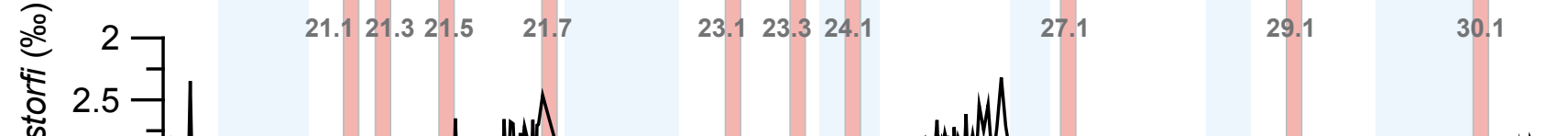

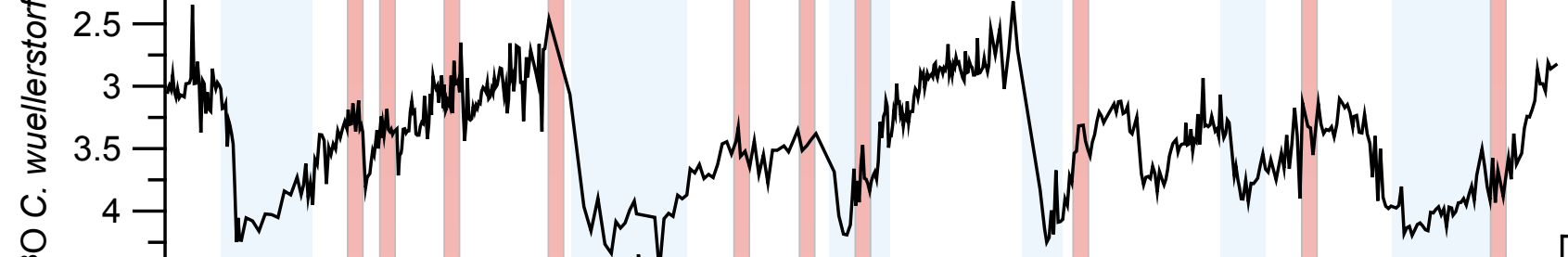

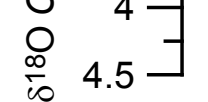
A) Mhe

竞 1.6 -

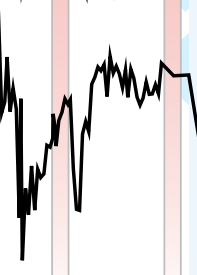

क 0

C)

C) $\quad \begin{array}{lllllllllllllll}780 & 800 & 820 & 840 & 860 & 880 & 900 & 920 & 940 & 960 & 980 & 1000 & 1020 & 1040 & 1060\end{array}$ Age (ka) 


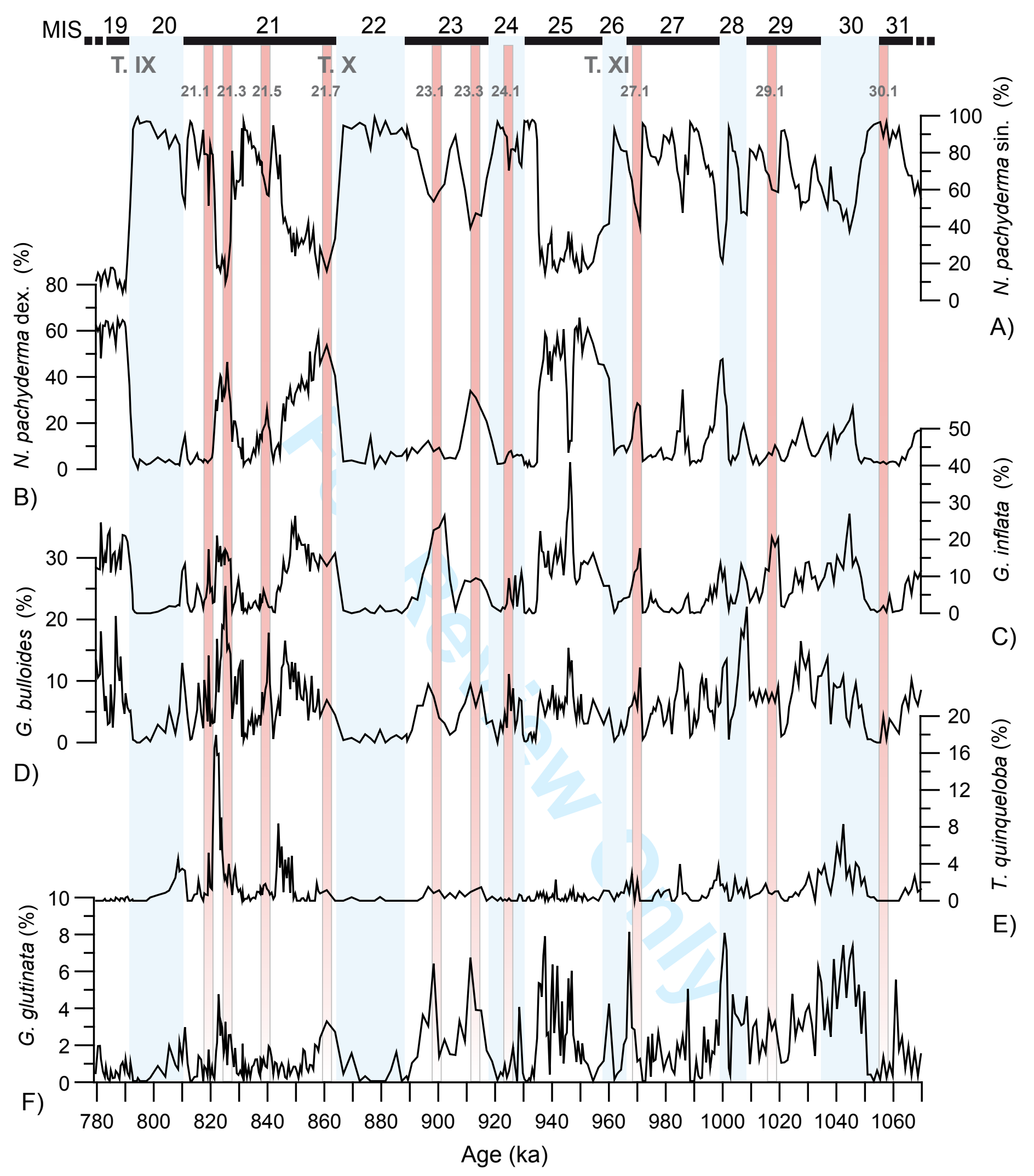



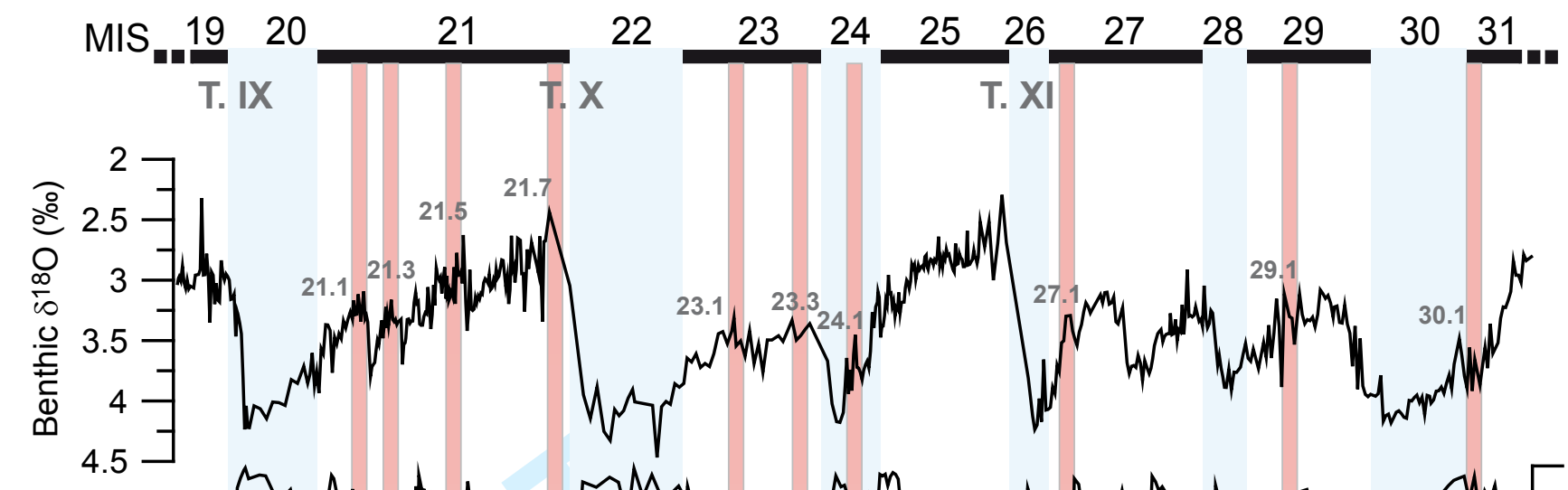

$4.5-$

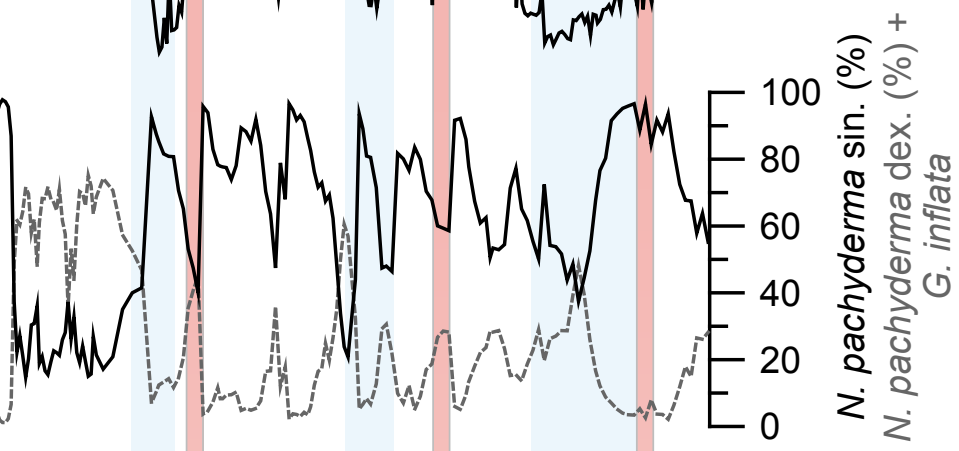
WW
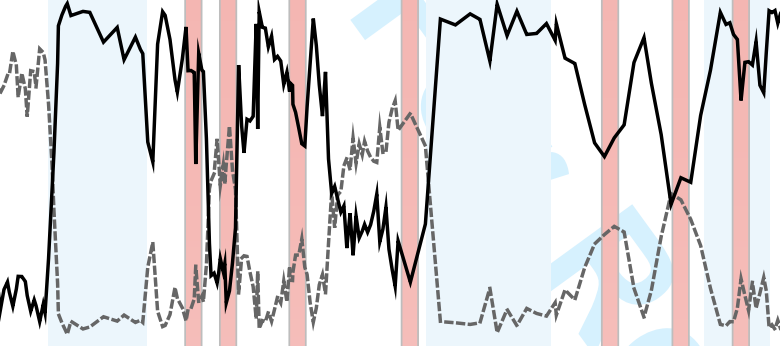

\begin{tabular}{ll}
8 & 1.6 \\
\hdashline & 1.2
\end{tabular}

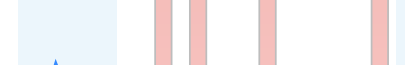

and
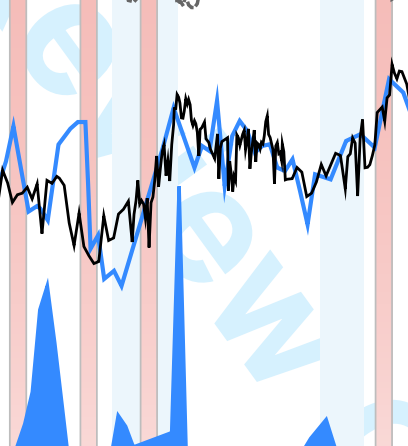

Mind

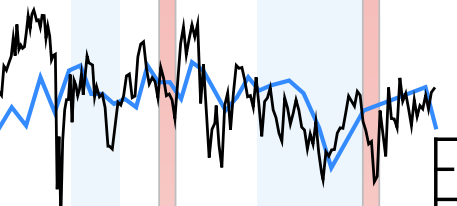

B)

E) $0-1$
$-0.4-7$

C)

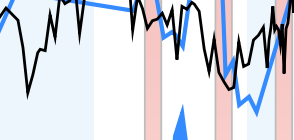
80

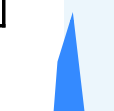

$+60-$

0
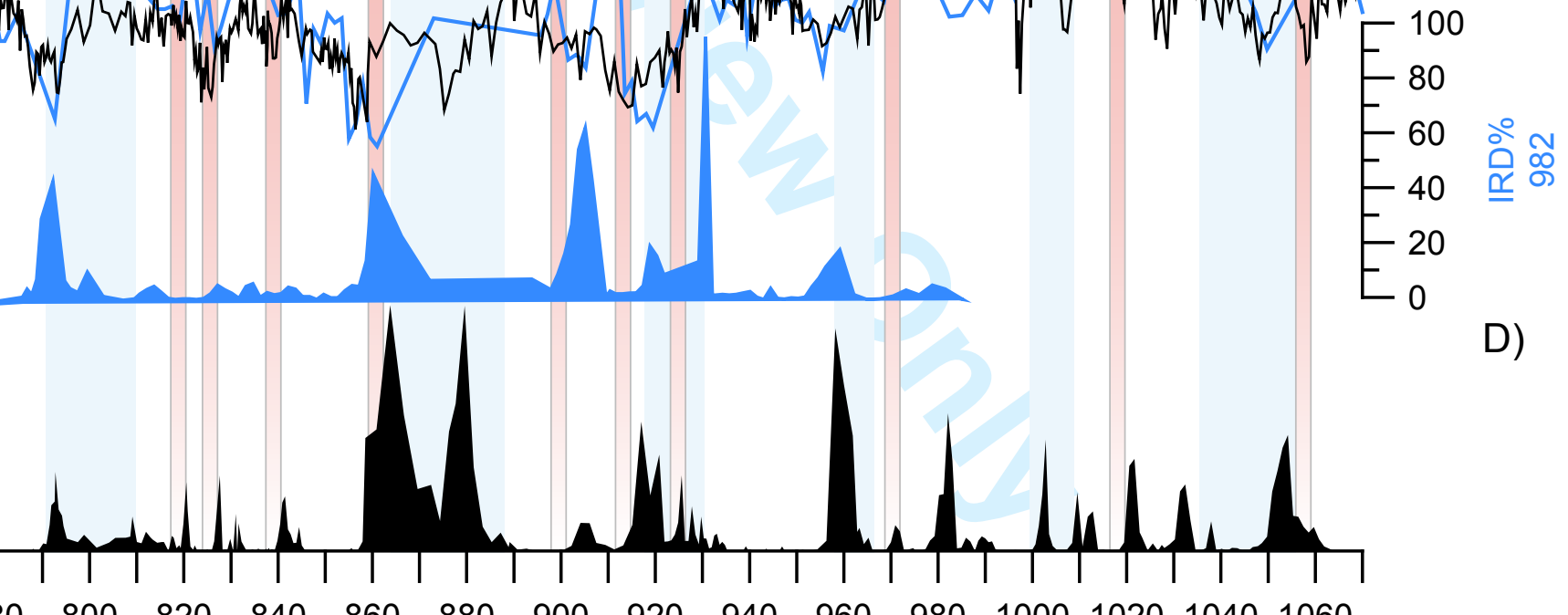


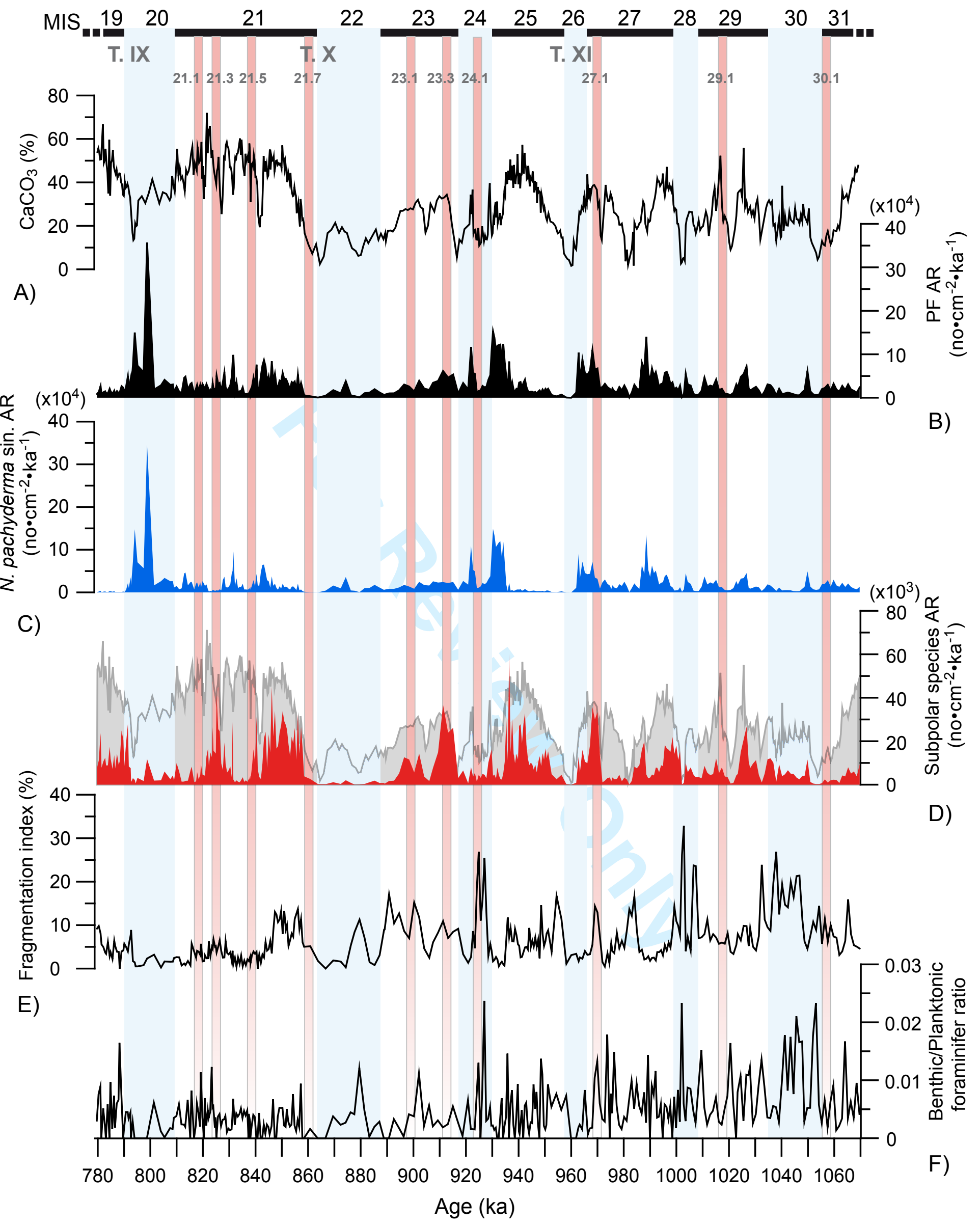




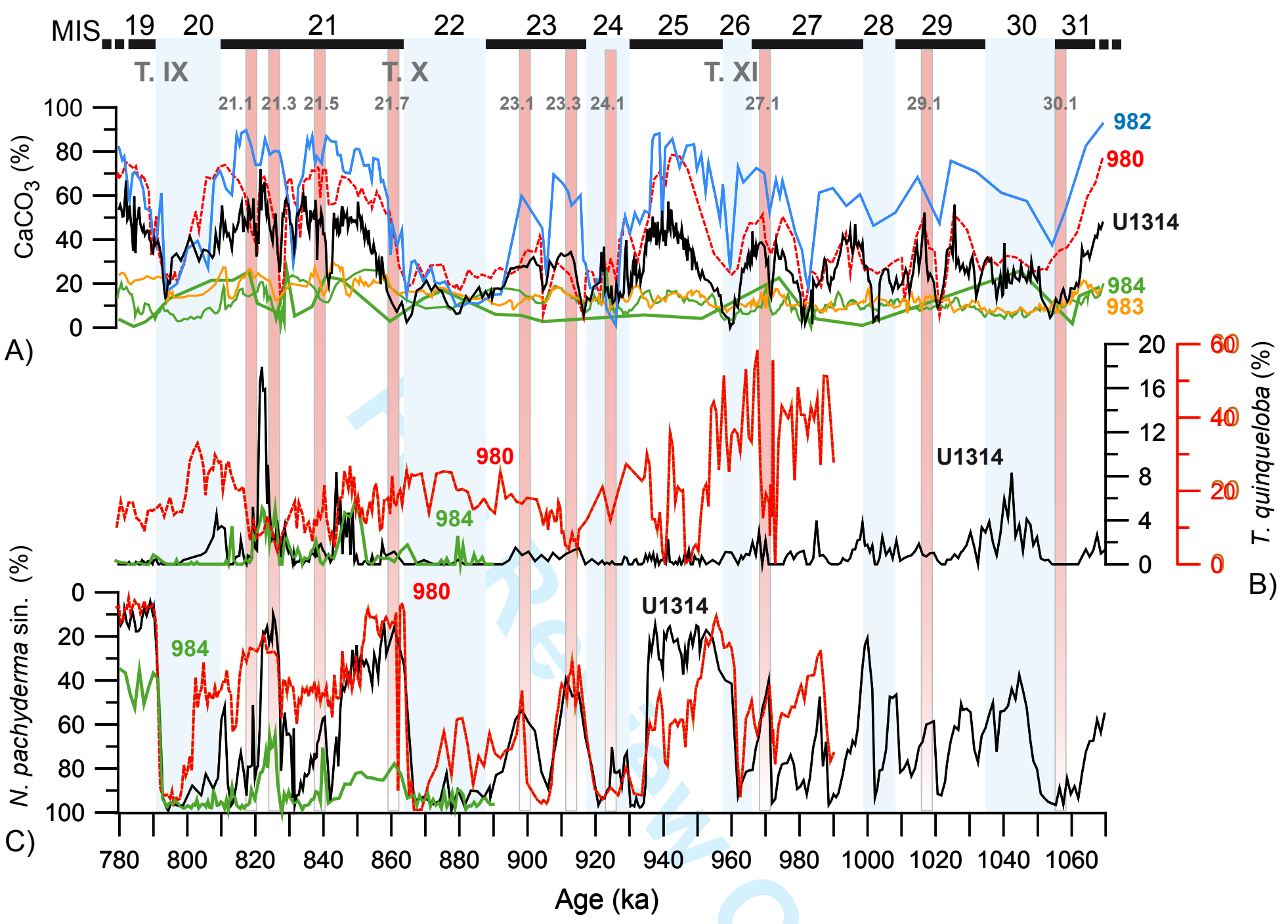


A

MIS 31-26

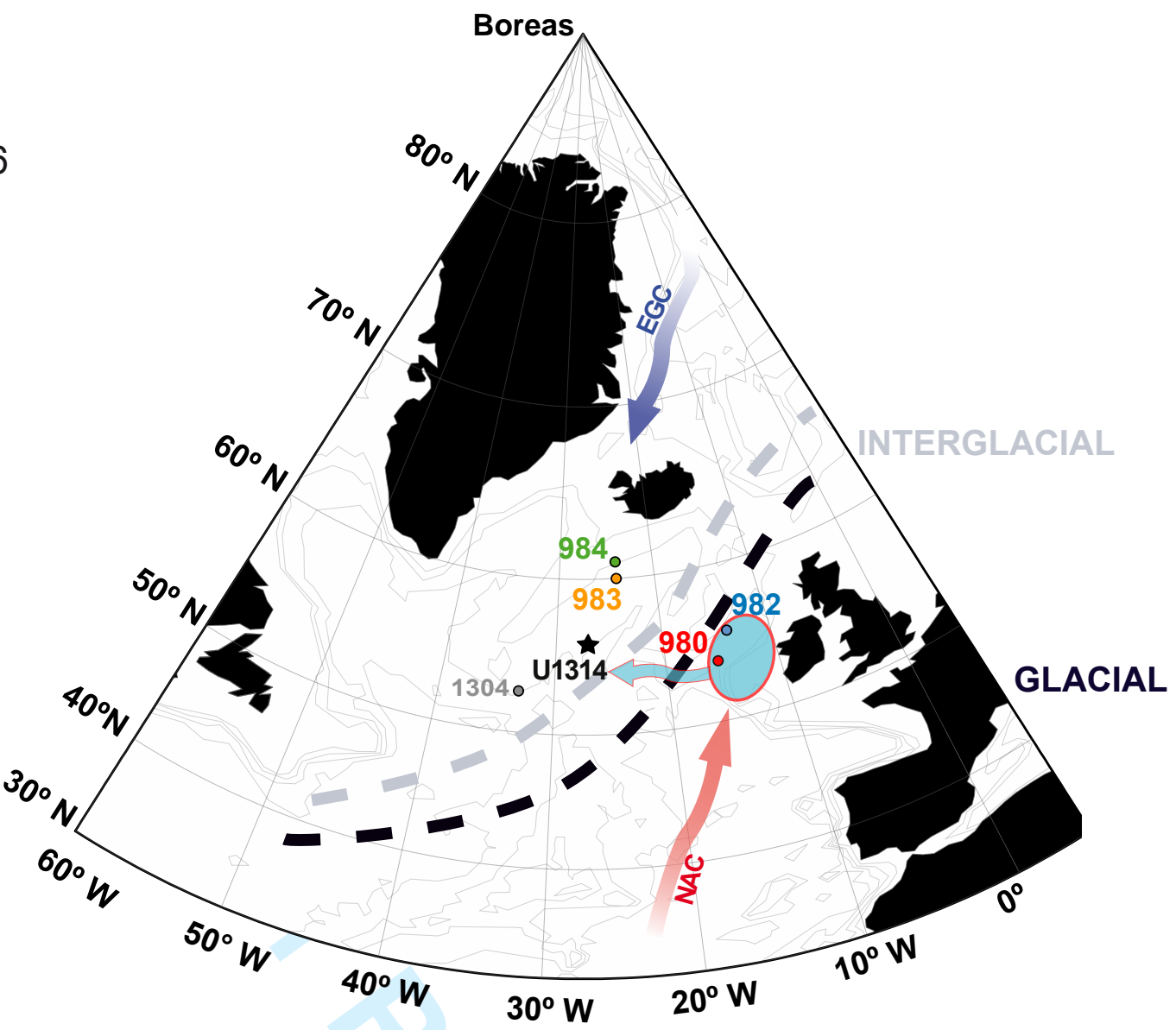

MIS 31-26

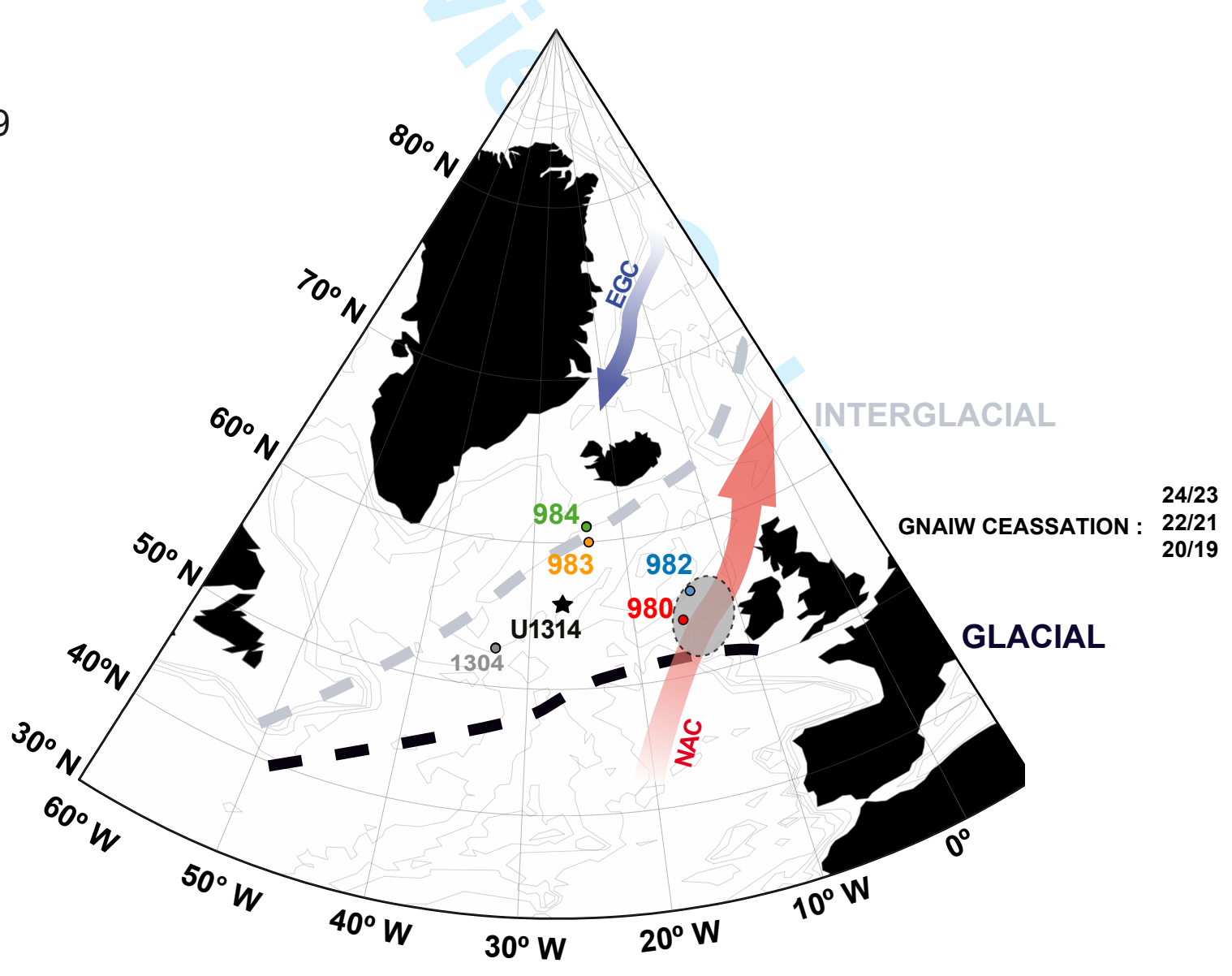

MIS 25-19

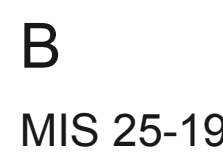




\begin{tabular}{|c|c|c|c|c|}
\hline Site & Latitude Longitude & Location & Data & Reference \\
\hline U1314 & $56^{\circ} 36^{\prime} \mathrm{N} \quad 27^{\circ} 88^{\prime} \mathrm{W}$ & Gardar Drift & fauna, IRD isotopes, $\mathrm{CaCO}_{3}$ & this study \\
\hline 983 & $60^{\circ} 23^{\prime} \mathrm{N} \quad 23^{\circ} 38^{\prime} \mathrm{W}$ & Gardar Drift & $\mathrm{CaCO}_{3}$ & $\begin{array}{c}\text { Baumann \& Huber (1999) } \\
\text { Ortiz et al. (1999) }\end{array}$ \\
\hline 984 & $61^{\circ} 25^{\prime} \mathrm{N} \quad 24^{\circ} 04^{\prime} \mathrm{W}$ & Bjorn Drift & fauna, $\mathrm{CaCO}_{3}$ & $\begin{array}{c}\text { Wright \& Flower (2002) } \\
\text { Ortiz et al. (1999) }\end{array}$ \\
\hline 980 & $55^{\circ} 29^{\prime} \mathrm{N} \quad 14^{\circ} 42^{\prime} \mathrm{W}$ & Feni Drift & fauna, $\mathrm{CaCO}_{3}$ & $\begin{array}{c}\text { Wright \& Flower (2002) } \\
\text { Ortiz et al. (1999) }\end{array}$ \\
\hline 982 & $57^{\circ} 30^{\prime} \mathrm{N} \quad 15^{\circ} 52^{\prime} \mathrm{W}$ & Rockall Plateau & IRD, isotopes, $\mathrm{CaCO}_{3}$ & $\begin{array}{c}\text { Venz et al. }(1999) \\
\text { Baumann \& Huber (1999) }\end{array}$ \\
\hline
\end{tabular}

